\title{
Fast food fever: reviewing the impacts of the Western diet on immunity
}

Ian A Myles

\begin{abstract}
While numerous changes in human lifestyle constitute modern life, our diet has been gaining attention as a potential contributor to the increase in immune-mediated diseases. The Western diet is characterized by an over consumption and reduced variety of refined sugars, salt, and saturated fat. Herein our objective is to detail the mechanisms for the Western diet's impact on immune function. The manuscript reviews the impacts and mechanisms of harm for our over-indulgence in sugar, salt, and fat, as well as the data outlining the impacts of artificial sweeteners, gluten, and genetically modified foods; attention is given to revealing where the literature on the immune impacts of macronutrients is limited to either animal or in vitro models versus where human trials exist. Detailed attention is given to the dietary impact on the gut microbiome and the mechanisms by which our poor dietary choices are encoded into our gut, our genes, and are passed to our offspring. While today's modern diet may provide beneficial protection from micro- and macronutrient deficiencies, our over abundance of calories and the macronutrients that compose our diet may all lead to increased inflammation, reduced control of infection, increased rates of cancer, and increased risk for allergic and auto-inflammatory disease.
\end{abstract}

\section{Introduction}

The Western diet is characterized by a high intake of saturated and omega- 6 fatty acids, reduced omega-3 fat intake, an overuse of salt, and too much refined sugar [1]. Most are aware that this type of eating, if not in moderation, can damage the heart, kidneys, and waistlines; however, it is becoming increasingly clear that the modern diet also damages the immune system. The modern lifestyle is also typified by reduced exposure to microorganisms, increased exposure to pollutions, heightened levels of stress, and a host of other exceptionally well reviewed variables that likely contribute to immune dysfunction [2]. Therefore, while dietary effects on immunity should not be thought of in isolation, herein we focus on the body of evidence detailing the mechanisms for the Western diet's impact on immune function.

\section{Total nutrient intake}

Intake of adequate calories and micronutrients is vital for optimal immune function. Deficiency in total calories

Correspondence: mylesi@niaid.nih.gov

Bacterial Pathogenesis Unit, Laboratory of Clinical Infectious Diseases, National Institute of Allergy and Infectious Diseases, National Institutes of Health, 9000 Rockville Pike Building 33, Room 2W10A, Bethesda, MD, 20892, Maryland

\section{() Biomed Central}

(c) 2014 Myles; licensee BioMed Central Ltd. This is an Open Access article distributed under the terms of the Creative Commons Attribution License (http://creativecommons.org/licenses/by/4.0), which permits unrestricted use, distribution, and reproduction in any medium, provided the original work is properly credited. The Creative Commons Public Domain Dedication waiver (http://creativecommons.org/publicdomain/zero/1.0/) applies to the data made available in this article, unless otherwise stated. and/or protein, as seen in parts of the world stricken with starvation, severely reduces the immune system's ability to respond [3]. As one example, inflammatory cytokines are themselves proteins, and thus infection during starvation can lead to the production of these cytokines at the expense of other proteins from blood and tissues [3]. However, the obesity epidemic clearly outlines that today's diet contains an over abundance of nutrients [1]. While the Western world is not free from micronutrient deficiencies, since this review aims at detailing the immuno-nutrition of a Western diet not typically characterized by micronutrient deficiency, they are thus considered outside the focus. Therefore, we encourage interested readers to seek out lovely review articles on the immune impacts and mechanistic understandings of dietary minerals and vitamins [3-6].

Adipocytes release inflammatory substances including interleukin (IL-) 1, IL-6, and tumor necrosis factor (TNF) [7]. In animal models, it appears that these signals can act as false alarms that, over enough time and in large enough amounts, cause the entire system to dial down its responsiveness - analogous to a person removing a battery from a twitchy smoke detector that frequently alarmed when no signs of fire were present $[7,8]$. When an actual infection comes along, the response 
may be delayed because the early warning system was silenced - just as deactivating that smoke detector leaves a home more susceptible to fire [7]. While human verification is lacking, this concept is not unique to immunity, for example anabolic steroid abusers down regulate their steroid responses [9] while opioid abusers down regulate innate opiate responses [10].

Obese individuals have fewer white blood cells to fight infection and those cells they do possess have reduced phagocytosis capability $[11,12]$. While a complex interplay of hormonal, metabolic, and immunologic processes contribute to the biologic responses in the obese the resultant immune dysfunction increases the risk of infections of the gums, respiratory system, and of surgical sites after an operation [13-17]. Even routine interventions like immunizations may not work as well simply due to the inability of the vaccination needle to reach the muscle tissue of the arm [18]. One possible mechanism for obesity's harmful effects on the immune system could be the increased levels of leptin in the blood. All mononuclear immune cells have a receptor for leptin and activation leads to an increase in IL-1, IL-6, and TNF [19]. Leptin stimulates NK cells, activates the transcription factor STAT3, and reduces the antiinflammatory T-regulatory (Treg) cells [20]. In general, adiponectin has opposing effects on immunity and interestingly the ratio of the two can predict the development of coronary artery disease in diabetics [21]. Hypothetically, as with the development of resistance to leptin's appetite suppressing functions [19], patients with obesity may, overtime, down-regulate the immune activation attributable to leptin [7]. However intriguing the in vitro impacts or correlation evidence of leptin may be, the precise mechanism by which excess calories impact the immune system has yet to be fully elucidated and will be very difficult to separate from the underlying mechanisms of the macronutrient sources of calories.

Eating disorders currently attributed to image obsession are also an unfortunate part of modern dietary habits and their immune impacts have gone relatively ignored compared to obesity. While the nutrient deficiencies seen in eating disorders are not nearly as severe as for the starvation seen in developing nations, subtle deficiencies appear to lead to subtle immune defects [22]. Both anorexia and bulimia may reduce neutrophil and monocytes numbers, T-cell number and function, antibacterial complement proteins, as well as effects attributable to any micronutrient deficiency that may develop [23]. Yet surprisingly, despite infection being a major cause of death in patients with anorexia, most are infection free until the late stages of their disease; speculation on the cause of this finding proposes that either the severe iron deficiency and sequestration render the blood a harsh environment for pathogen survival or that anorexic patients are, typically, deficient in carbohydrates and calories but may be only moderately deficient in proteins and fat $[22,23]$. Further investigation into the immune impacts of eating disorders is warranted.

\section{Sugars, salt, and fats \\ Sugar}

In vitro evidence suggest processed, simple sugars also reduce white blood cell phagocytosis and possibly increase inflammatory cytokine markers in the blood $[24,25]$; of note, the author's attribute their findings more to the relative glycemic load of meals than the sugars themselves and the most direct study on sugar's effect on lymphocyte function is now four decades old and thus, repeat investigation employing in vivo and/or modern techniques is required. Meanwhile, the complex carbohydrate fiber (but not starches), such as that found in fruits and vegetable, appear to reduce inflammation in both humans [26-32] and mice [33]. The impacts of artificial sweeteners are less clear; provocative, yet highly limited, evidence implicates saccharin and sucralose as contributors to Crohn's and Ulcerative Colitis via interference with homeostatic inactivation of digestive proteases [34,35]. However this evidence is only epidemiologic correlation and animal modeling, and lacks direct human investigation. Other studies looking at the effects of sweeteners in cell culture suggest antiinflammatory effects in the blood [36,37]. Few studies on newer sweeteners have been conducted, yet limited cell-culture evidence on stevioside suggests antiinflammatory properties while improving phagocytosis and mitogen responses for both $\mathrm{T}$ and $\mathrm{B}$ cells [38-40]. Potential immune impacts of the newest sweetener, mongroside $\mathrm{V}$, have not been directly investigated. Therefore, definitive commentary on the immune impacts of sweeteners will require further investigation.

\section{Salt}

Animal studies suggest that high salt in the diet might also increase IL-17-mediated inflammation and could worsen autoimmune diseases, although predictions on how this may affect humans should only be seen as preliminary $[41,42]$. There is however ample evidence on how dietary fat affects the immune system.

\section{Saturated fatty acids}

One potentially harmful effect of fat is enhancement of the prostaglandin system as it feeds into the arachadonic and prostaglandin E2 $\left(\mathrm{PGE}_{2}\right)$ pathways [43]. $\mathrm{PGE}_{2}$ is pro-inflammatory, increasing IL-17 production and macrophage activation among other pathways [43]. Additionally, dietary fats alter the lipids of the membranes of immune cells, disrupting the immune functions $[44,45]$. Yet perhaps the most concerning aspect of modern 
dietary fat is its ability to directly trigger the inflammatory process.

One of the first-line weapons the immune system deploys against infection are molecules called Toll-like receptors (TLR). While complex in its workings, when the immune system comes across a potential invader these receptors are designed to evaluate if it is bacterial, viral, or fungal. If the body finds evidence of any of these organisms, the immune system can begin its attack immediately while the adaptive immune system assesses what specific pathogen it is facing [46]. One of the TLR weapons, TLR4, is designed to sense bacteria. Unfortunately the part of the bacteria TLR4 binds, lipopolysaccharide (LPS), contains mostly saturated palmitic and steric fatty acids [47-51]. Meaning that TLR4 can generate inappropriate signaling when exposed to certain saturated fats if in too great of frequency, amount, or homogeneity rather than in a more biological balance and dosage. Any resultant, abnormal signaling may lead to a misguided attack upon saturated fat when it is perceived as a bacterial invader [9,47-54]. The resulting inflammation in the gut can lead to a break down of barriers, allowing harmful substance to leak from the gut into the blood stream and contribute to immune dysfunction that worsens infection control $[52,54,55]$. Consistent with these in vitro and animal models, studies in humans reveal down regulation of TLR4 and increased LPS translocation occurring within hours of a bolus of saturated fat $[54,56]$, while polymorphisms reducing TLR4 functioning are relatively protective against dyslipidemia, coronary artery disease, and metabolic syndrome $[57,58]$. Saturated fats interact with another bacterial receptor, TLR2 and its co-receptor CD14 (which is shared with TLR4), and thus may impact infectious outcomes for both Gram-negative infections such as $E$. coli as well as Gram-positive infections like Staph. aureus and have even be implicated in coronary artery disease pathogenesis $[49,52,59,60]$.

\section{Omega-6 fatty acids}

While saturated fats are the most inflammatory [50,61,62], overabundance of omega-6 (n-6) poly-unsaturated fats, such as those found in most cooking oils, have also been implicated in immune response through several mechanisms including effects on TLR4 [53] and serving as precursors for inflammatory mediators [63-67]. However, a recent review of human trials seems to undermine evidence supporting n-6 intake increases inflammation [68]. The meta-analysis found the only measured mediator that was significantly altered by an increase in dietary linoleic acid was $\mathrm{PGE}_{2}$ and concluded that the lack of detectable impact in human clinical trials indicates that the cell-culture and animal based evidence against $n-6$ fails to accurately reflect the complexity of human physiology. However, one confounder shared by many of the clinical trials investigating the immune impacts of fatty acids may be their exclusion of unhealthy subjects and subsequent lack of disease context. While retrospective studies are limited in their own ways, an intervention study investigating an ubiquitous exposure like dietary n-6 that excludes everyone with pre-existing inflammation may be excluding the biologically susceptible portion of the population and thus may be predestined to find no impact of their intervention; while the lack of baseline inflammation in clinical trails could alleviate the concern for omega- 6 as a universal inducer of chronic inflammation, since these trials occur in the absence of either infectious challenge or underlying inflammatory disorders they make no comment on potential for n-6 intake to impact the risk for, control of, or inflammation during, acute pathology. Additionally, clinical trials involving $n-6$ have yet to measure inflammatory markers that are downstream of the elevated $\mathrm{PGE}_{2}$ (such as IL-17 and the Th17 pathway) [43] or directly investigate the TLR4 axis, and instead focus on the more traditional Th1 markers of TNF, C-reactive protein (CRP), or cardiovascular disease [69]. Furthermore, inflammation limited to the small bowel may not elevate typical blood inflammatory markers that are measured in these clinical trials despite imparting pathology [70]. Thus, further investigation into the immune impacts of omega- 6 will be needed before any definitive connection between the provocative in vitro findings and human disease pathology can be stated.

\section{Omega-3 fatty acids}

The immune impact of trans unsaturated fatty acids (trans fats) have gone under investigated whilst researchers focus on their deleterious cardiovascular effects, however one study found an increase in IL- 6 and CRP but only in the overweight female subgrouping [71]. In contrast, omega-3 (n-3) poly-unsaturated fats are generally associated with anti-inflammatory effects [63,72-74]. Dietary n-3 may have beneficial effects on a variety of conditions with inflammatory components, such as atherosclerosis and cardiovascular disease [73], inflammatory bowel [63], and allergic diseases [75,76]. Maternal intake of $n-3$ during pregnancy protects against the development of allergic and inflammatory disease in infants and children whereas diets rich in saturated and/or n-6 fats were associated with an increased risk $[75,77]$. Furthermore, $\mathrm{n}-3$ directly interacts with transcription factors such as NFKB and PPAR- $\gamma$ to downregulate the expression of pro-inflammatory genes [63,73] and inhibits activation of TLR4 [48]. Omega-3 may further regulate the immune response through resolvins and protectins, anti-inflammatory mediators synthesized from eicosapentaenoic acid (EPA) and docosahexaenoic acid (DHA) [72,78-80]. These mediators reduce inflammationinduced neutrophil infiltration, promote the scavenging of 
inflammatory chemokines [79], and enhance macrophage phagocytosis to clear apoptotic cells [72]. Animal models also suggest omega-3 serves as an antiinflammatory balance to modulate TLR2- and TLR4dependent inflammation $[45,81,82]$. Thus, another potential contributor to modern diet-induced immune dysfunction may be the increased consumption of omega-6 in lieu of omega-3 fatty acids [1].

\section{Gluten}

Recent animal and cell-culture models have found that elements in gluten can stimulate inflammation through TLR4 [83]; while these findings are afar from conclusive and require human correlation, they do conjure intriguing speculation given the current gluten-free dietary trend. This mechanism, even if eventually validated in humans, is in contrast with the reported primary mechanism of celiac disease; in celiac sprue, people with a very specific genetic pre-disposition have an error in gluten processing that leads to a different and more severe kind of immune activation. Dietary gluten is modified by tissue trans-glutaminases and, normally, proteins are digested by antigen presenting cells (APC) such as dendritic cells or B-cells; the proteins are then presented on a major histocompatibility complex (MHC) to T-cells for evaluation and, if deemed foreign, induce immune activation. In patients with celiac, a particular MHC receptor, either HLA-DQ2 or HLA-DQ8, allows the processed gluten to act as a sort of super-antigen, binding the APC to the CD4+ T-cell without going through normal processing; this inappropriately activates the T-cell and results in inflammation and symptoms [84-87]. However, HLA-DQ2 and HLA-DQ8 are found in approximately $40 \%$ of the US population and yet only roughly $1 \%$ of the US carries the diagnosis of celiac $[88,89]$. Therefore, some additional undiscovered mechanisms as well as genetic and/or environmental risk factors must be present.

\section{The microbiome and inheritance}

The notion that diet, stress, and environment can, for better or worse, imprint upon the bowel has been around since the ancient Egyptian pharaohs [90]. However, only recent focus and technologic advances have allowed accurate elucidation of the mechanisms by which our lifestyle impacts our microbiome and leads to dysbiosis. In the gut (and on the skin), there is an optimal, albeit not yet fully elucidated, balance of bacterial species. Some strains of bacteria are needed to digest dietary fibers [91] while others produce valuable nutrients like vitamin $K$ [92]. Beneficial bacteria aide their hosts by occupying space and/or modifying the microenvironment in ways that prevent harmful bacteria from gaining a foothold [91]. More importantly, the commensal flora provides a type of training to the immune system. Like a sparing partner in boxing, the immune system's interactions with the normal commensal flora provides an education that is indispensable when a pathogenic opponent is encountered. The current understanding on how dietary fats alter the microbiome include TLR4-dependent induction of local inflammation leading to altered host environment, shifts in immune cell membrane functions, and changes in nutrient availability favoring some organisms over others $[47,52,93]$ (Figure 1A). Dietary simple sugars appear to lead to dysbiosis directly through changes in local nutrient concentrations and bacterial functions that may favor harmful taxa over the beneficial commensals [92,94-103]. Interesting preliminary culture-based and animal research has shown the gut microbiome to possess the ability to metabolize the artificial sweeteners considered otherwise non-caloric for humans. While results must be interpreted cautiously, gut bacteria can process sweeteners into various shortchain fatty acids (SCFA) that hold a wide array of potential consequences [104]; while some SCFA may be beneficial, their production may shift the bacterial balance $[105,106]$, may be processed into absorbable byproducts that provide calories, and interestingly may activate the TLR4 pathway $[104,107]$.

What is perhaps of larger concern is that the harmful effects of diet can actually stretch across generations. A mother's diet may potentially shape her child's flavor preferences even before birth, potentially skewing their palette towards anything from vegetables to sugary sweets in ways that could influence subsequent propensity for obesity and/or unhealthy dieting [108]. In addition, children inherit their microbiome from their mother mostly through parturition but also during breast-feeding and development until the bacterial balance matures around two to four years of age $[92,109]$. However, recent evidence suggests that the microbiome may also be seeded into the unborn fetus while still in the womb $[109,110]$ (Figure 1B). When the mother's diet causes a harmful imbalance of her bacteria, she passes this imbalance on to her child and thus fails to present the ideal commensals for a proper immune education during her child's most critical developmental window [52]. This developmental dysbiosis leaves the offspring's immune system poorly trained to fight off infections and encourages autoimmune and allergic diseases [52]. In mice, high dietary saturated fat solely during lactation led to a pro-inflammatory milk via a TLR2/4-dependent but microbiome-independent manner, furthering that saturated fat has additional direct harm to the newborn beyond the indirect harm steaming from dysbiosis [111]. Just as loss of honeybees from orchards or addition of an invasive species to a lake creates significant 


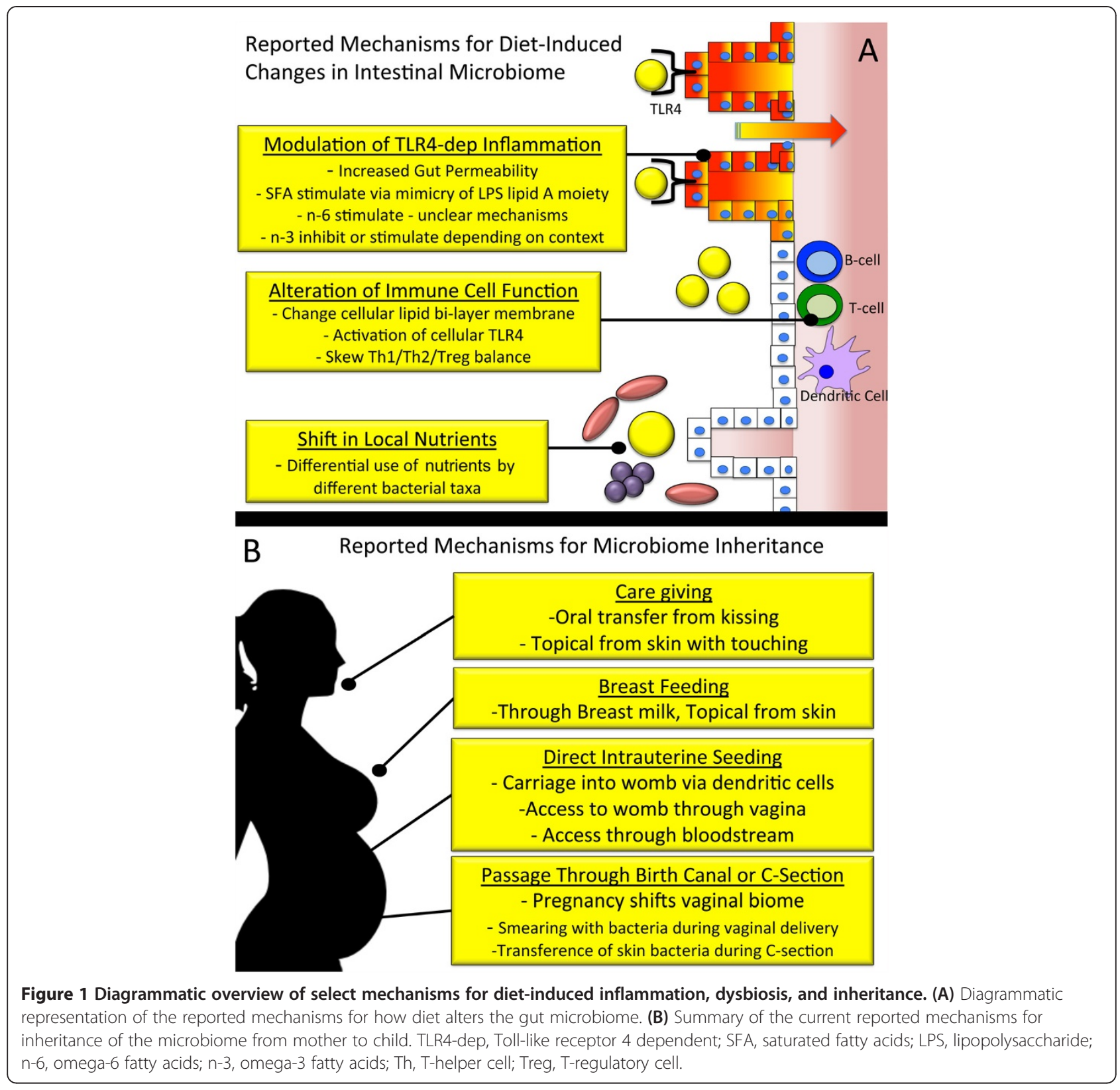

harm for the surrounding biosphere, so too it appears that small shifts in our microbiome caused by today's unhealthy diets can reverberate through human health.

However, lest fathers believe that their diet does not impact the offspring, paternal epigenetics related to methylation of DNA and histones can also be inherited by the offspring and could alter early development of the immune system [52]. Epigenetic changes in DNA are, in effect, cellular memory; these changes prevent dividing pancreas cells from becoming cells of the kidney or any other organ [112]. This memory is so essential that many neoplasms begin with a cell's loss of the epigenetic memory learned during embryogenesis [113,114]. Since the information encoded upon DNA is passed from parent-to-child and even potentially from parent-tograndchild, cells that learn bad habits like ignoring signs of infection or over-reacting to antigens could combine with microbiome shifts to further worsen a child's immunologic development $[112,115,116]$. The degree to which shifts in the microbiome can affect epigenetic changes in DNA, and vice versa, is currently not fully understood.

In addition to altering TLR-mediated inflammation and potentially DNA epigenetics, a mechanism by which alteration in microflora may drive immune-mediated disease involves the gut bacteria's effect on regulatory T-cells (Tregs), the cell tasked with keeping the immune system in balance during both inflammation and homeostasis 
[117]. Alterations in the microbiome have been shown in both mice and (to a less extensive degree) humans to affect Treg development [118-122], and reduction in Treg signal is associated with worse outcomes in infection control [123], autoimmunity [124,125], allergic sensitization [126], and has been, more controversially, associated with cancer risks [127-129]. Recent mouse work has also shown transplanting the gut flora from allergic mice to wild type mice can significantly alter oral allergic sensitization [130], indicating direct effects of the gut flora on immune disease. Therefore, dietary choices that alter gut microbiome likely alter systemic responses through changes in the number and function of regulatory $\mathrm{T}$ cells.

Unraveling which specific bacterial strains are either the protectors or pathogens has not yet been elucidated in either mice or humans, however the field of microbiota research has many informative discoveries. The desire to foster a healthy microbiome is the driving force behind the therapeutic use of probiotics. Some studies have shown a positive impact for probiotic use including numerous and well reviewed immune beneficial effects of Lactobacillus species including alleviating traveler's diarrhea, reducing respiratory infections, and serving as adjunct treatment for allergic rhinitis, asthma, and atopic dermatitis [116]. Supplementation with various Lactobacillus, Lactococcus, and Bifidobacterium species reduce the rate and severity of childhood atopic dermatitis when fed to pregnant women during the later weeks of gestation [131]. Additional studies have made use of transgenic bacteria producing the anti-inflammatory cytokine IL-10 to aide Crohn's treatment [132] and even found relief of anxiety and depression through bacteria that naturally produce serotonin [133,134]. Evidence outlining associations between natural shifts in the microbiome and impacts on human health is also plentiful. In general, increased numbers Firmicutes relative to Bacteroidetes is associated with an increased incidence of allergy, asthma, and obesity [135]. As stated, processed sugars and saturated fats encourage dysbiosis [52,92] while complex carbohydrates encourage an anti-inflammatory microbiome and discourage growth of infections from Clostridium difficile [92]. Intake of omega-3 increases ratios of Blautia species and increases levels of both colonic and blood IL-10 in mice, although a direct link between the two was not established [136]. Reductions in Blautia were found in children with type-I diabetes [137] and, among other changes, was associated with increased incidence of colorecal cancer in both humans [138] and mice [139]. However, high levels of Blautia were seen in human patients with inflammatory bowel disease [140], possibly revealing differences between human and mouse biology or perhaps representing a natural attempt to restore homeostasis. Reduction in Eubacterium is associated with increased incidence of Crohn's disease [141] while increased presence is associated with both irritable bowel syndrome [142] and inflammatory bowel disease [143]. Meanwhile, Clostridium coccodies and C. leptum are protective against inflammatory bowel disease [92]. Furthering the complexity is the notion that any specific taxa altered by diet may represent a so-called "keystone species", a species exerting greater effect than their numbers would suggest. As such, we cannot exclude any shift in the gut microflora as the etiology of immune alterations.

However, any hope for long-term benefits from probiotics may be limited by the need for dietary modification. Gordon and colleagues demonstrated that alterations in the mouse gut microbiome could prevent obesity, however these effects were dependent upon changing from a highfat, low-fiber Western-style diet, to a healthier standard mouse diet [144]. While these findings are limited to mice, they raise a concern that taking probiotics may not be of benefit if the patient fails to eat a healthy diet. Additional, recent mouse studies [145] investigating how consumption of red meat may accelerate cardiovascular disease and inflammation in humans $[146,147]$ suggest an additional and potentially serious limitation on probiotic supplementation. Dietary L-carnitine and choline, compounds abundant in red meat, are metabolized into trimethylamine- $\mathrm{N}$-oxide (TMAO) by way of some normal gut commensals; in mice TMAO enhances atherosclerosis through disrupting cholesterol metabolism and foam-cell macrophage activity [145]. This may suggests that researchers cannot assume the safety of probiotic supplementation since bacterial species providing benefit to healthy individuals eating a healthy diet may hold the potential to become pathogenic when exposed to an unhealthy diet; however, like all studies limited to mice, human correlation will be needed. The benefits of dietary modification over supplementation is furthered by evidence showing that dietary supplementation does not increase longevity, indicating that probiotics and other commercial interventions such as tea or berry extracts are unlikely to counteract poor dietary habits [148]. Much work remains before the understanding of the effects of dysbiosis in humans reaches that of mice, however while definitive statements may be lacking, the preponderance of current evidence strongly suggests that the gut microbiome is a major contributor to human health and disease. The effects of macromolecules and immune function and dysbiosis are summarized in Figure 2.

\section{Immuno-nutrition in cancer}

Although dietary factors are thought to account for up to one-third of cancers in Western nations [149], the complexity of immuno-nutrition is well highlighted in the research relating to cancer prevention. A typical meal may have thousands to bioactive compounds [150], distinguishing the effects of one from another is made all the more difficult by evidence that compounds may synergize or inhibit each other in respect to the development of 


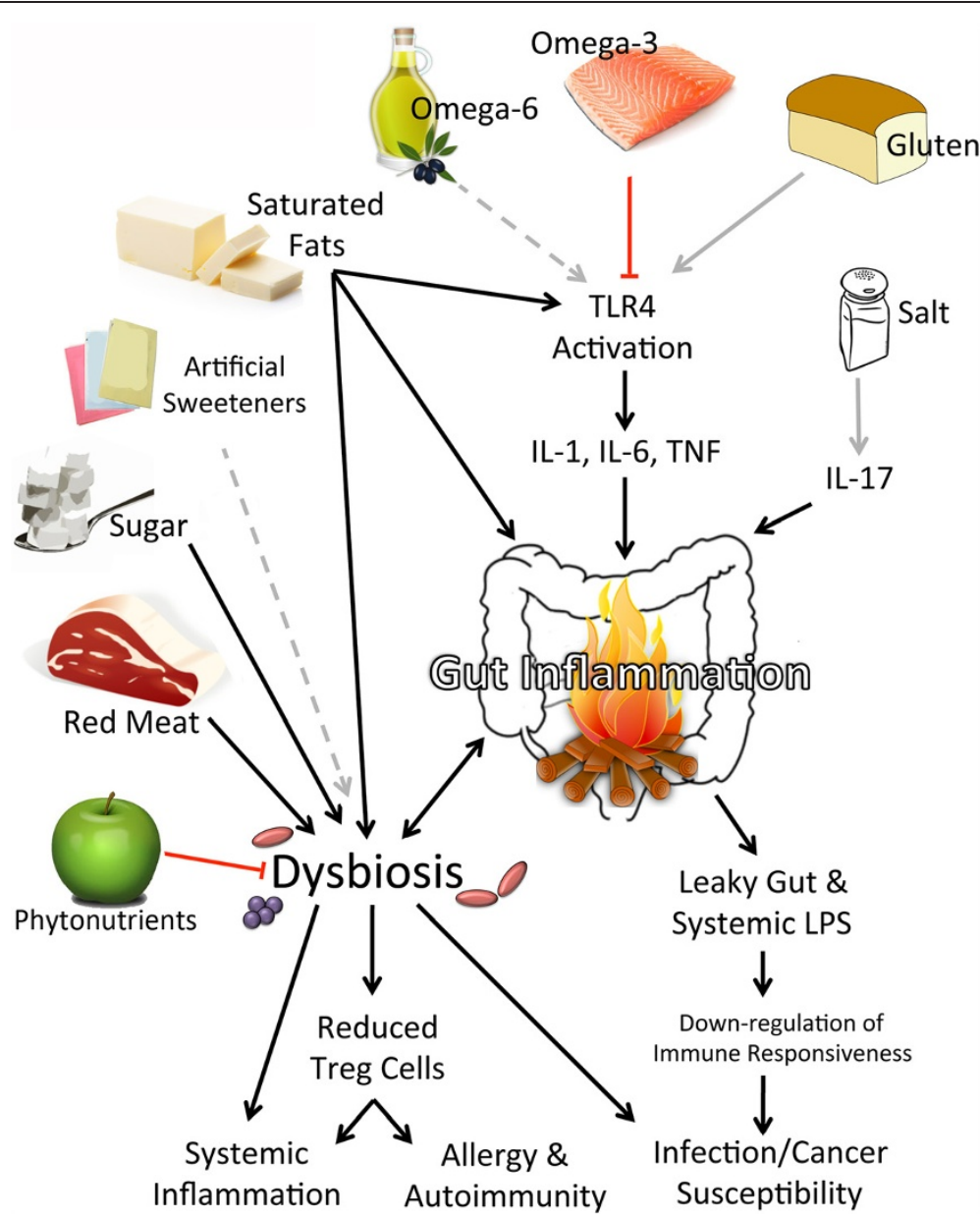

Figure 2 Diagrammatic overview of the current mechanisms for macro-components of the modern diet altering susceptibility to infection, allergy, and autoimmunity. Solid black lines indicate direct human evidence for enhancement is present; solid red lines indicate direct human evidence of inhibition exists; grey lines indicate only in vitro or animal model evidence exist currently; dotted lines indicate significant disagreement within the scientific literature. TLR4, Toll-like receptor 4; IL-, Interleukin; TNF, tumor necrosis factor; Treg, T-regulatory cell. All clip art and images sourced from free-for-us online repositories.

neoplasms [151,152] as well as possible confounding by other environmental exposures such as smoking and infections (H. pylori for stomach [153], hepatitis B and C for liver [154], and Human-papilloma virus for cervical [154]). In general, chronic inflammation is associated with an increased risk of cancer [155], whether this is due to direct cellular damage, the previously discussed resultant down regulation of immune responsiveness, or a combination is unknown. There are associations between oral and esophageal cancers and high intake of alcohol, tobacco, and of scalding hot food or drinks [156]. Colon cancer risk appears to be worsened by high intake of red meat, salt-preserved meat, and fat, although the data is not completely conclusive [157-159]. Excessive intake of alcohol is associated with cirrhosis-induced liver cancer and is a risk factor for breast cancer $[149,160]$. Evidence on dietary risk factors for pancreatic, lung, prostate, and kidney are more controversial, but have been exquisitely reviewed [149].
Palmitic acid may potentiate iron-mediated toxicities and increase the rates of DNA mutations while inhibiting the normal apoptotic pathways [161-163]. Dietary intake of the saturated palmitic and steric fatty acids as well as the omega- 9 oleic acid, may be independent risk factors for the development of colon cancer [164]. Simple sugars were thought to heighten cancer risk through several well-reviewed in vitro mechanisms [165], however more recent clinical analysis has not shown an increased risk of cancer attributable to sugar intake and suggests the original findings are more likely related to total caloric intake or glycemic load [166-168]. There is however, convincing evidence that obesity itself increases the risk of cancers of the breast, uterus, colon, esophagus, and kidney [169-171].

There is some evidence suggesting anti-tumor properties for vitamin E [172-175], vitamin D [176], and selenium among others [177]; the details of which have been 
well reviewed [150,178,179]. Meanwhile, initial excitement regarding pre-operative supplementation with omega-3 fatty acids improving outcomes in patients undergoing gastrointestinal cancer surgery $[164,180]$ and for betacarotine as a therapeutic in lung cancer has lessened after failures in double-blind follow up trails [181-183]. Overall, recent failed investigations into nutritional supplementation and cancer prevention may have weakened the enthusiasm for use of synthetic multivitamins in the prevention of cancer [182-185], perhaps indicating that the beneficial effects seen with increased natural consumption of these products $[179,186-189]$ is due to bioactive compounds other than the measured vitamins or, more likely, that there are differences in how isolated synthetic molecules behave outside of the context of the intact food product. Not that use of supplements for other goals is unwarranted (such as iron for anemia or calcium and vitamin D for bone health) but for immune health, it appears whole dietary sources harbor the truly beneficial properties.

The exact mechanism of how any individual dietary element impacts cancer development is far from fully understood. Many of the reportedly protective vitamins and minerals share anti-oxidant properties, suggesting a mechanism more related to protection of DNA from damage than altered immune function [190-193]. Dietary modifications of the epigenetic methylation silencing of tumor suppressor and promoter genes have also been implicated [194,195]. Additionally, a number of association studies in humans and mice have linked the development of colon cancer to dysbiosis, particularly an increase in $S$. bovis and certain adhesive/invasive strains of E. coli [196-199]. Yet, while the role in, and mechanism for diet-induced immune dysfunction in cancer development cannot be outlined declaratively, given the association of neoplasms with certain dietary choices it seems unlikely that diets that worsen infection and/or induce chronic inflammation will be benign.

\section{Genetically modified (GM) foods}

Another area of concern involves genetically modified organisms (GMO) in the food supply. While the debate around GM foods tends to be conducted in an all-aregood or all-are-bad format, some distinctions are notable in the literature. Potential benefits are highlighted by GM rice strains modified to produce high levels of betacarotene. Vitamin A deficiency severely impairs immune function and thus any alleviation could produce dramatic benefit in parts of the world with both low nutrient supply and high exposure to pathogens [200]. While not without vocal detractors [201], use of GM rice is equivalent to supplement pills at providing adequate intake of vitamin A in children and thus offers a potentially life-saving benefit, as delivering beta-carotene through rice would be easier and more economically sustainable than through medication [202]. Whether sourcing vitamin A from GM crops suffers from the same shortcoming that pill-based supplementation have in regards to improving clinical outcomes [182] remains to be seen. Another potential benefit of GM technology, enhancement of crop yields, appears highly dependent on the specific modification in question and the area into which it is being deployed. Modifications that protect plants against select caterpillars or beetles greatly improve yield in places stricken with these pests, such as in parts of India [203], but make no measurable impact in places without infestations, such as the United States or Europe [204]. However, modification that impart drought-resistance to crops may hold promise for improving crop yields in parts of the United States, although their effects on human health are as yet untested [205]. Thus, modifications may protect against the harmful impacts of malnutrition, but only if they are correctly targeted [206].

The possibility of inducing allergic reactions through genetic modification was outlined when genetic elements from Brazil nuts were grafted into soy with deleterious consequences [207]. However, today GM food products must be screened for homology against all known allergens and future genetic modifications may even remove allergenic proteins from the common allergenic foods [208]. Yet, concerning evidence does exist against certain GM food practices. While many genetic modifications represent the grafting of one naturally occurring and routinely encountered gene into a commonly eaten food, others signify what can be thought of as "selfspraying" elements; some GM plants internally produce pesticides or pesticide inhibitors in a manner that holds little functional difference from externally spraying the compound - examples include Bacillus thuringiensis (Bt) producing and glyphosate-resistance plants. Since pesticide-resistance genes tend to encourage increased use of pesticides [204], it is a concerning finding that pesticides like glyphosate induces cellular death in human umbilical, placental, embryonic, and peripheral blood mononuclear cells at physiologic levels [209-211]; further studies will be needed to either confirm or alleviate these concerns. In animal models, the combination of pesticide-producing GM maize and pesticide-resistant GM soy led to increased rates of severe stomach inflammation [212], although GM maize alone did not have significant effects on either inflammation or the make up of the gut microbiome of pigs [213] and direct consumption of high doses of Bt insecticide did not induce acute toxicity in humans or toxicity in mice [214].

However, an additional concern was raised when studies revealed that functional genes, from both industrial and natural sources, ingested by animals could be internalized by gut bacteria, these bacteria transcribe the engrafted genes into functional proteins, and the genetic 
changes could be inherited by offspring via microbiome transfer [215-218]. Human corollary was uncovered when researchers showed that an intact and functional industrial gene could be found in bacteria from the small bowel of patients with ileostomies [219]. Research subjects with intact gastrointestinal tracts did not show evidence of the gene surviving the large bowel. While the authors concluded that such modifications were safe because only a small number of small-bowel bacteria expressed the functional pesticide-resistance gene, the hypothetical potential for transferring the production of harmful compounds to the microbiome in a manner that would circumvent gastric-acid inactivation was shown. In theory, the ability to transfer genetics to the gut microbiome could be utilized for therapeutic purposes, but would be limited by the need to assure consistent and non-toxic levels. Yet while the lack of direct investigation into the human health impacts of GM foods preclude definitive comment to either confirm or alleviate the concern for harm, research on industrial GM crops are subject to patent-law limitations, meaning that any report of findings must have the manufacturer's approval prior to publication [220]. Thus the potential for conflict of interest and suppression of evidence exists and paradoxically may fuel some of the scientific ignorance and mistrust driving the all-or-none debate.

\section{Immunity driving nutrition}

The original name for TNF-alpha was cachectin, derived from its observed ability to induce profound weight loss (cachexia) and appetite suppression [221]. Although the exact pathology is complex, patients with chronic infections could find their appetite chemically blocked, opening the possibility for further worsening of immune function and infection from poor nutrient intake. Loss of appetite and depression from some pro-inflammatory cytokines [2] may limit palatable food options in ways that increase the risk for nutrient deficiencies. Pro-inflammatory cytokines also affect the glucocorticoid pathway, with implications on cortisol physiology and thus on stress, metabolism, and development [221].

Beyond the well-known common antigens, coloring and flavoring additives such as annatto and carmine may cause anaphylaxis in sensitized patients and drive labeling laws that influence dietary choices [222]. Unfortunately, earlier recommendations for allergen avoidance during pregnancy, breast feeding, and the child's early years may have done little to decrease allergic disease burden; while definitive conclusions cannot yet be drawn, current evidence does not support allergen avoidance during gestation or nursing, and preliminary results from ongoing studies have suggested early introduction of foods may prove to be protective [223,224]. Allergic disease may subsequently drive limitation in nutritional choices such as in children with atopic dermatitis whom tend to avoid nuts, dairy, egg, fish, wheat, and/or artificial colorings [225]. While every child should be evaluated for nutritional deficiencies on an individual basis, children on allergy-driven elimination diets have an increased risk for calcium and omega-3 deficiency [225,226]. Therefore, clinicians should be attuned to both the emotional and immunologic impacts of chronic inflammation and immune dysfunction in their patients.

\section{Economic considerations}

Financial limitations are often cited as a primary factor behind the higher consumption of unhealthy food products in a nation's poor [227,228]. Yet, rising medical costs stemming from diet-related illness have extended these economic limitations into middle-income families [229] and are thus capable of generating a downward spiral of poor diet begetting medical illness, illness increasing poverty, and poverty further entrenching a poor diet. However, burdensome out-of-pocket medical costs [230] may be forcing our society to realize that no matter how much cheaper a pro-inflammatory meal may be at the register, the cost savings will be quickly erased by any resultant medical illness. Costs of obesity not shouldered by the patient are also mounting, one 2010 study asserts that obese Americans will average additional annual medical cost on the order of $\$ 1,152$ for men and $\$ 3,613$ for women when you factor in loss of productivity; subjects that were significantly underweight also saw increased medial bills [231]. Irrespective of whether such expenses are carried by a system that is fully socialized, privatized, employer-based, or any combination therein, dietary choices will have large-scale impacts on the economy. While poverty will continue to limit dietary options, some fast food chains are improving the health of their menus [232], for example where there was once only soda and fries as fast food side items, many chains now offer options for apples and milk. This trend will hopefully continue and perhaps even spread to the sadly lagging convenience stores and, in particular, the processed food manufacturers [232,233] if the public furthers the realization that cheap food is not inexpensive if it is also unhealthy.

\section{Caveats}

While the plentiful bounty of the Western world may protect us from the harmful immune effects of microand macronutrient deficiencies, the over abundance of many substances simultaneously enhance inflammation while muting our immune system's ability to respond to and ultimately control infections. The nutritional elements discussed herein are certainly not the entire explanation for the disease patterns seen in industrialized societies, and additional immune harms stemming from our increasingly sedentary lifestyles, altered infectious 
Table 1 Summary of the immune impacts of dietary components and the nutritional impacts of various disease states

\begin{tabular}{|c|c|c|c|c|c|}
\hline Macronutrient & Immunologic impact & $\begin{array}{l}\text { In vitro } \\
\text { evidence }\end{array}$ & $\begin{array}{l}\text { Animal } \\
\text { models }\end{array}$ & Human evidence & Reviews \\
\hline \multirow[t]{3}{*}{ Simple sugars } & - Reduced phagocytosis & \multirow[t]{3}{*}{24} & \multirow[t]{3}{*}{-} & \multirow[t]{3}{*}{$\mathbf{2 5}, 94-95,100, \mathbf{1 0 1}, 102$} & \multirow{3}{*}{$\begin{array}{l}92,103 \\
104\end{array}$} \\
\hline & - Increased inflammatory cytokines production & & & & \\
\hline & - Dysbiosis & & & & \\
\hline \multirow{3}{*}{$\begin{array}{l}\text { Complex } \\
\text { sugars }\end{array}$} & - Reduced inflammatory cytokine production & \multirow[t]{3}{*}{27} & \multirow[t]{3}{*}{33} & \multirow[t]{3}{*}{$\mathbf{2 7}, 28,29-30,31$} & \multirow[t]{3}{*}{26,32} \\
\hline & $\begin{array}{l}\text { - As part of intact food substance, may reduce risk } \\
\text { of certain diseases }\end{array}$ & & & & \\
\hline & - Reduced dysbiosis & & & & \\
\hline \multirow{3}{*}{$\begin{array}{l}\text { Artificial } \\
\text { sweeteners }\end{array}$} & - Mostly unknown or unproven & \multirow[t]{3}{*}{$36-37,104-107$} & \multirow[t]{3}{*}{35,40} & \multirow[t]{3}{*}{34} & \multirow[t]{3}{*}{-} \\
\hline & $\begin{array}{l}\text { - Potential contributor to inflammatory bowel } \\
\text { disease }\end{array}$ & & & & \\
\hline & $\begin{array}{l}\text { - Stevioside may enhance phagocytosis and T/B-cell } \\
\text { mitogen responses }\end{array}$ & & & & \\
\hline Salt & $\begin{array}{l}\text { - May increase IL-17 and worsen autoimmune } \\
\text { disorders }\end{array}$ & - & $41-42$ & - & - \\
\hline \multirow[t]{5}{*}{ Saturated fat } & $\begin{array}{l}\text { - Alterations in prostaglandin pathway and } \\
\text { antioxidant mechanisms }\end{array}$ & \multirow[t]{5}{*}{$\begin{array}{l}45,47-49,59 \\
61-62,161-163\end{array}$} & \multirow[t]{5}{*}{$50-52,55,60$} & \multirow[t]{5}{*}{$\mathbf{5 4}, \mathbf{5 6}, 57-58,164$} & \multirow[t]{5}{*}{$\begin{array}{l}43-44 \\
53,63\end{array}$} \\
\hline & - TLR2, and TLR4 activation; CD14 alterations & & & & \\
\hline & $\begin{array}{l}\text { - Increase gut inflammation and reduce gut barrier } \\
\text { function }\end{array}$ & & & & \\
\hline & $\begin{array}{l}\text { - Worse outcomes in sepsis; Increased risk of } \\
\text { autoimmunity, allergy, certain neoplasms }\end{array}$ & & & & \\
\hline & - Dysbiosis & & & & \\
\hline \multirow[t]{2}{*}{ Trans fat } & - Mostly unknown & \multirow[t]{2}{*}{-} & \multirow[t]{2}{*}{-} & \multirow[t]{2}{*}{-} & \multirow[t]{2}{*}{64} \\
\hline & - Increased IL-6 and CRP levels & & & & \\
\hline \multirow{2}{*}{$\begin{array}{l}\text { Omega-6 fatty } \\
\text { acids }\end{array}$} & - Increased inflammation via TLR4 activation & \multirow[t]{2}{*}{67} & \multirow[t]{2}{*}{52,66} & \multirow[t]{2}{*}{65,68} & \multirow[t]{2}{*}{53,64} \\
\hline & - Dysbiosis & & & & \\
\hline $\begin{array}{l}\text { Omega-3 fatty } \\
\text { acids }\end{array}$ & $\begin{array}{l}\text { - Reduced inflammatory cytokines and transcription } \\
\text { factors }\end{array}$ & 48,74 & $80-82,136$ & $75-77$ & 63, \\
\hline & - Increased resolvin and protecin production & & & & \\
\hline & - Increased IL-10 & & & & \\
\hline Gluten & $\begin{array}{l}\text { - Possible TLR4 activation; studies limited to animal } \\
\text { models }\end{array}$ & 83 & 83 & $84-87$ & 88-89 \\
\hline & $\begin{array}{l}\text { - Induction of Celiac symptoms in patients with } \\
\text { HLA-DQ2 or HLA-DQ8 }\end{array}$ & & & & \\
\hline Red meat & - Mostly unproven; studies limited to animal models & - & 145 & 142,147 & 64,149 \\
\hline & $\begin{array}{l}\text { - Increased endothelial inflammatory, activation of } \\
\text { foam-cell macrophages }\end{array}$ & & & & \\
\hline Genetic & - Mostly unknown & $209-211$ & $212-218$ & 202, 207, 219 & - \\
\hline modification & $\begin{array}{l}\text { - Reduction vitamin A or calorie deficiency } \\
\text { depending on modification/location of } \\
\text { deployment }\end{array}$ & & & & \\
\hline & - No apparent impact on allergic disease & & & & \\
\hline & - Increased exposure to pesticides & & & & \\
\hline & $\begin{array}{l}\text { - Potential for transmission of functional genes into } \\
\text { small bowel bacteria }\end{array}$ & & & & \\
\hline
\end{tabular}


Table 1 Summary of the immune impacts of dietary components and the nutritional impacts of various disease states (Continued)

\begin{tabular}{|c|c|c|c|c|c|}
\hline $\begin{array}{l}\text { Pathologic } \\
\text { disorder }\end{array}$ & Effect on nutrition and/or immunity & $\begin{array}{l}\text { In vitro } \\
\text { evidence }\end{array}$ & $\begin{array}{l}\text { Animal } \\
\text { models }\end{array}$ & Human evidence & Reviews \\
\hline \multirow[t]{5}{*}{ Obesity } & $\begin{array}{l}\text { - Increased inflammatory cytokines, immunologic } \\
\text { tolerance to inflammatory cytokines }\end{array}$ & \multirow[t]{5}{*}{12} & \multirow[t]{5}{*}{19} & \multirow[t]{5}{*}{$11,13-15,16-18,21,169-171$} & \multirow[t]{5}{*}{$\begin{array}{l}7,20 \\
149\end{array}$} \\
\hline & - Reduced leukocyte numbers and function & & & & \\
\hline & $\begin{array}{l}\text { - Reduced control of infection, heightened rates of } \\
\text { certain neoplasms }\end{array}$ & & & & \\
\hline & - Overproduction and eventual tolerance of leptin & & & & \\
\hline & - Dysbiosis & & & & \\
\hline \multirow[t]{3}{*}{$\begin{array}{l}\text { Anorexia and } \\
\text { bulimia }\end{array}$} & $\begin{array}{l}\text { - Reduced monocyte, neutrophil, and T-cell } \\
\text { numbers and function }\end{array}$ & \multirow[t]{3}{*}{-} & \multirow[t]{3}{*}{-} & \multirow[t]{3}{*}{22} & \multirow[t]{3}{*}{23} \\
\hline & - Reduced complement function & & & & \\
\hline & - Any disorders related to micronutrient disorders & & & & \\
\hline \multirow[t]{6}{*}{ Dysbiosis } & $\begin{array}{l}\text { - Maternal transmission leading to immune } \\
\text { alterations in the offspring }\end{array}$ & \multirow{6}{*}{$\begin{array}{l}47,96-98 \\
104-107 \\
198-199\end{array}$} & \multirow[t]{6}{*}{$\begin{array}{l}52,93,111 \\
139,144,196\end{array}$} & \multirow[t]{6}{*}{$\begin{array}{l}94-95,100, \mathbf{1 0 1}, 102,109,110, \mathbf{1 1 6} \\
\mathbf{1 3 1 - 1 3 5}, 138,141-143,197\end{array}$} & \multirow[t]{6}{*}{$\begin{array}{l}91-92 \\
99,103\end{array}$} \\
\hline & $\begin{array}{l}\text { - Epigenetic changes altering offspring immunity } \\
\text { via paternal inheritance }\end{array}$ & & & & \\
\hline & - Reduced regulatory T cell numbers & & & & \\
\hline & $\begin{array}{l}\text { - Worse outcomes in sepsis; Increased risk of } \\
\text { autoimmunity and allergy }\end{array}$ & & & & \\
\hline & - May increase likelihood of obesity & & & & \\
\hline & - May increase risk of certain neoplasms & & & & \\
\hline \multirow{2}{*}{$\begin{array}{l}\text { Chronic } \\
\text { inflammation }\end{array}$} & - Reduced appetite and weight loss & \multirow[t]{2}{*}{-} & \multirow[t]{2}{*}{-} & \multirow[t]{2}{*}{155} & \multirow[t]{2}{*}{2} \\
\hline & - May increase risk of certain neoplasms & & & & \\
\hline Food allergy & $\begin{array}{l}\text { - Avoidance diets predisposing to deficiency in } \\
\text { calcium and omega-3 }\end{array}$ & - & - & $222, \mathbf{2 2 3}, 224,226$ & - \\
\hline
\end{tabular}

Citations are organized by the primary models used in the research, cell culture (In vitro), animal, or direct human effects. For studies involving human data: further notation indicates cross-sectional studies (standard font); longitudinal study designs both prospective or retrospective or reviews discussing longitudinal evidence (italic font); or interventional trials or reviews discussing intervention studies (bold font). The citations provided are not meant to be all-inclusive and thus additional cited reviews of note are also provided; no additional annotation is provided in the review article column.

exposures, as well as increased exposure to pollutants warrant their own reviews $[2,234,235]$. We should note that the Western diet's additional, more established, propensity for damaging metabolic homeostasis also causes secondary immune dysfunction through resultant diseases such as diabetes, adding greater emphasis on eating a healthy diet; the impacts of diet on the risk of metabolic disorders and the immune defects in diabetes have also been well reviewed [236-240]. Additionally, although less established, the impacts of exercise on immunity and overall health are worthy of separate examination [241,242]. One final caveat of note is that many of the studies cited employ isolated nutrients for testing, and thus an interesting area for further research will be the difference between consumption of these items in their naturally diverse combinations as compared to the homogenized forms found in processed foods or supplements; peanuts, for example, may contain over eight different fatty acids [243], fruits have varying ratios of simple and complex carbohydrates, whereas many convenience foods contain a predominance of oleic and palmitic saturated fatty acid, omega- 6 fats, and fructose syrups [1,244-246]. In effect, we must investigate the difference between teaching the body to harvest fat, carbohydrates, and protein from a proverbial fish rather than giving the body these pre-extracted nutrients.

\section{Conclusions}

Table 1 serves as a summary outline of the data on immuno-nutrition focused upon in this review. In summary, there is enough quality, direct human evidence to conclude that many of the dietary choices in today's modern society appear to have harmful impacts on our immune system and likely on the immune system of our offspring; while many of the remaining conclusions related to the modern diet's deleterious influence can only be extrapolated from in vitro and/or animal models, given the sheer volume of evidence, predictions of similar human harm seem far from unreasonable (Table 1). Although promise remains, it also appears unlikely that synthetic supplements or probiotics will be able to fully counterbalance the damage of our dietary choices, let 
alone undo them, if they are not accompanied by lifestyle modifications. Of potentially greatest concern, our poor dietary behaviors are encoded into both our DNA scaffolding and gut microbiome, and thus these harmful immune modifications are passed to our offspring during their most critical developmental window. Therefore, given the scope of influence, the vast economic impacts, and the potential for trans-generational inheritance, the dietary impacts on immune health should thus, at minimum, be afforded a level of attention equal to that given to the dietary impacts on cardiovascular health.

\section{Competing interests}

The author declares that he has no competing interests.

\section{Acknowledgments}

This work was supported by the Intramural Research Program of The National Institutes of Health and The National Institute of Allergy and Infectious Disease. I.M. was responsible for all contributions related to this manuscript. The author would like to thank Nathan Pincus for assisting in the literature search, his friend William Howard for providing lively topical discussions, and above all Jennifer Myles for the inspiration.

Received: 10 March 2014 Accepted: 23 May 2014

Published: 17 June 2014

\section{References}

1. (USDA) USDoA: Profiling Food Consumption in America. Washington, DC: Book AF; 2002

2. Rook GA: 99th Dahlem conference on infection, inflammation and chronic inflammatory disorders: darwinian medicine and the 'hygiene' or 'old friends' hypothesis. Clin Exp Immunol 2010, 160:70-79.

3. Cunningham-Rundles S, McNeeley DF, Moon A: Mechanisms of nutrient modulation of the immune response. J Allergy Clin Immunol 2005, 115(6):1119-1128. quiz 1129.

4. Erickson KL, Medina EA, Hubbard NE: Micronutrients and innate immunity. $J$ Infect Dis 2000, 182(Suppl 1):S5-S10.

5. Miller J, Gallo RL: Vitamin D and innate immunity. Dermatol Ther 2010, 23:13-22.

6. Cassat JE, Skaar EP: Iron in infection and immunity. Cell Host Microbe 2013, 13:509-519.

7. Milner JJ, Beck MA: The impact of obesity on the immune response to infection. Proc Nutr Soc 2012, 71:298-306.

8. Pascual G, Glass CK: Nuclear receptors versus inflammation: mechanisms of transrepression. Trends Endocrinol Metab 2006, 17:321-327.

9. Buttner $A$, Thieme D: Side effects of anabolic androgenic steroids: pathological findings and structure-activity relationships. Handb Exp Pharmacol 2010, 195:459-484.

10. Harrison LM, Kastin AJ, Zadina JE: Opiate tolerance and dependence: receptors, G-proteins, and antiopiates. Peptides 1998, 19:1603-1630.

11. Nieman DC, Henson DA, Nehlsen-Cannarella SL, Ekkens M, Utter AC Butterworth DE, Fagoaga OR: Influence of obesity on immune function. J Am Diet Assoc 1999, 99:294-299.

12. Ghanim H, Aljada A, Hofmeyer D, Syed T, Mohanty P, Dandona P: Circulating mononuclear cells in the obese are in a proinflammatory state. Circulation 2004, 110:1564-1571.

13. Falagas ME, Kompoti M: Obesity and infection. Lancet Infect Dis 2006, 6:438-446.

14. Vilar-Compte D, Mohar A, Sandoval S, de la Rosa M, Gordillo P, Volkow P: Surgical site infections at the National Cancer Institute in Mexico: a case-control study. Am J Infect Control 2000, 28:14-20.

15. Dossett LA, Dageforde LA, Swenson BR, Metzger R, Bonatti H, Sawyer RG, May AK: Obesity and site-specific nosocomial infection risk in the intensive care unit. Surg Infect (Larchmt) 2009, 10:137-142.

16. Ylostalo P, Suominen-Taipale L, Reunanen A, Knuuttila M: Association between body weight and periodontal infection. J Clin Periodontol 2008, 35:297-304
17. Jedrychowski W, Maugeri U, Flak E, Mroz E, Bianchi I: Predisposition to acute respiratory infections among overweight preadolescent children: an epidemiologic study in Poland. Public Health 1998, 112:189-195.

18. Eliakim A, Schwindt C, Zaldivar F, Casali P, Cooper DM: Reduced tetanus antibody titers in overweight children. Autoimmunity 2006, 39:137-141.

19. Frederich RC, Hamann A, Anderson S, Lollmann B, Lowell BB, Flier JS: Leptin levels reflect body lipid content in mice: evidence for diet-induced resistance to leptin action. Nat Med 1995, 1:1311-1314.

20. Carbone F, La Rocca C, Matarese G: Immunological functions of leptin and adiponectin. Biochimie 2012, 94:2082-2088.

21. Finucane FM, Luan J, Wareham NJ, Sharp SJ, O'Rahilly S, Balkau B, Flyvbjerb A, Walker M, Hojlund K, Nolan JJ, Savage DB: Correlation of the leptin: adiponectin ratio with measures of insulin resistance in non-diabetic individuals. Diabetologia 2009, 52:2345-2349.

22. Marcos A, Nova E, Montero A: Changes in the immune system are conditioned by nutrition. Eur J Clin Nutr 2003, 57(Suppl 1):S66-S69.

23. Marcos A: The immune system in eating disorders: an overview. Nutrition 1997, 13:853-862.

24. Sanchez A, Reeser JL, Lau HS, Yahiku PY, Willard RE, McMillan PJ, Cho SY, Magie AR, Register UD: Role of sugars in human neutrophilic phagocytosis. Am J Clin Nutr 1973, 26:1180-1184.

25. Sorensen $L B$, Raben A, Stender S, Astrup A: Effect of sucrose on inflammatory markers in overweight humans. Am J Clin Nutr 2005, 82:421-427.

26. Suter PM: Carbohydrates and dietary fiber. Handb Exp Pharmacol 2005, 170:231-261.

27. Estruch R, Martinez-Gonzalez MA, Corella D, Basora-Gallisa J, Ruiz-Gutierrez V, Covas Ml, Fiol M, Gomez-Gracia E, Lopez-Sabater MC, Escaoda R, Pena MA, Diez-Espino J, Lahoz C, Lapetra J, Saez G, Ros E: Effects of dietary fibre intake on risk factors for cardiovascular disease in subjects at high risk. J Epidemiol Community Health 2009, 63:582-588.

28. Herder C, Peltonen M, Koenig W, Sutfels K, Lindstrom J, Martin S, llanne-Parikka P, Eriksson JG, Aunola S, Keinanen-Kiukaanniemi S, Valle T, Uusitupa M, Kolb H, Toumilehto J: Anti-inflammatory effect of lifestyle changes in the Finnish Diabetes Prevention Study. Diabetologia 2009, 52:433-442.

29. Ajani UA, Ford ES, Mokdad AH: Dietary fiber and C-reactive protein: findings from national health and nutrition examination survey data. J Nutr 2004, 134:1181-1185.

30. Qi L, van Dam RM, Liu S, Franz M, Mantzoros C, Hu FB: Whole-grain, bran, and cereal fiber intakes and markers of systemic inflammation in diabetic women. Diabetes Care 2006, 29:207-211.

31. Ma Y, Griffith JA, Chasan-Taber L, Olendzki BC, Jackson E, S tanek EJ, 3rd Li W, Pagoto SL, Hafner AR, Ockene IS: Association between dietary fiber and serum C-reactive protein. Am J Clin Nutr 2006, 83:760-766.

32. Kuo SM: The interplay between fiber and the intestinal microbiome in the inflammatory response. Adv Nutr 2013, 4:16-28.

33. Trompette A, Gollwitzer ES, Yadava K, Sichelstiel AK, Sprenger N, Ngom-Bru C, Blanchard C, Junt T, Nicod LP, Harris NL, Marsland BJ: Gut microbiota metabolism of dietary fiber influences allergic airway disease and hematopoiesis. Nat Med 2014, 20:159-166.

34. Qin X: Etiology of inflammatory bowel disease: a unified hypothesis. World J Gastroenterol 2012, 18:1708-1722.

35. Qin XF: Impaired inactivation of digestive proteases by deconjugated bilirubin: the possible mechanism for inflammatory bowel disease. Med Hypotheses 2002, 59:159-163.

36. Szucs EF, Barrett KE, Metcalfe DD: The effects of aspartame on mast cells and basophils. Food Chem Toxicol 1986, 24:171-174.

37. Rahiman F, Pool EJ: The in vitro effects of artificial and natural sweeteners on the immune system using whole blood culture assays. J Immunoassay Immunochem 2014, 35:26-36.

38. Sehar I, Kaul A, Bani S, Pal HC, Saxena AK: Immune up regulatory response of a non-caloric natural sweetener, stevioside. Chem Biol Interact 2008, 173:115-121.

39. Boonkaewwan C, Toskulkao C, Vongsakul M: Anti-inflammatory and immunomodulatory activities of stevioside and its metabolite steviol on THP-1 Cells. J Agric Food Chem 2006, 54:785-789.

40. Yingkun $N$, Zhenyu W, Jing L, Xiuyun L, Huimin Y: Stevioside protects LPS-induced acute lung injury in mice. Inflammation 2013, 36:242-250,

41. Kleinewietfeld M, Manzel A, Titze J, Kvakan H, Yosef N, Linker RA, Muller DN, Hafler DA: Sodium chloride drives autoimmune disease by the induction of pathogenic TH17 cells. Nature 2013, 496:518-522. 
42. Wu C, Yosef N, Thalhamer T, Zhu C, Xiao S, Kishi Y, Regev A, Kuchroo VK: Induction of pathogenic $\mathrm{TH} 17$ cells by inducible salt-sensing kinase SGK1. Nature 2013, 496:513-517.

43. Kalinski P: Regulation of immune responses by prostaglandin E2. $\mathrm{J}$ Immunol 2012, 188:21-28.

44. Calder PC: Fatty acids and inflammation: the cutting edge between food and pharma. Eur J Pharmacol 2011, 668(Suppl 1):S50-S58.

45. Kim K, Jung N, Lee K, Choi J, Kim S, Jun J, Kim E, Kim D: Dietary omega-3 polyunsaturated fatty acids attenuate hepatic ischemia/reperfusion injury in rats by modulating toll-like receptor recruitment into lipid rafts. Clin Nutr 2013, 32:855-862.

46. Beutler BA: TLRs and innate immunity. Blood 2009, 113:1399-1407.

47. Huang S, Rutkowsky JM, Snodgrass RG, Ono-Moore KD, Schneider DA Newman JW, Adams SH, Hwang DH: Saturated fatty acids activate TLR-mediated proinflammatory signaling pathways. J Lipid Res 2012 53:2002-2013

48. Lee JY, Sohn KH, Rhee SH, Hwang D: Saturated fatty acids, but not unsaturated fatty acids, induce the expression of cyclooxygenase-2 mediated through Toll-like receptor 4. J Biol Chem 2001, 276:16683-16689.

49. Nguyen MT, Favelyukis S, Nguyen AK, Reichart D, Scott PA, Jenn A, Liu-Bryan R, Glass CK, Neels JG, Olefsky JM: A subpopulation of macrophages infiltrates hypertrophic adipose tissue and is activated by free fatty acids via Toll-like receptors 2 and 4 and JNK-dependent pathways. J Biol Chem 2007, 282:35279-35292.

50. Shi H, Kokoeva MV, Inouye K, Tzameli I, Yin H, Flier JS: TLR4 links innate immunity and fatty acid-induced insulin resistance. J Clin Invest 2006, 116:3015-3025.

51. Reynolds CM, McGillicuddy FC, Harford KA, Finucane OM, Mills KH, Roche HM: Dietary saturated fatty acids prime the NLRP3 inflammasome via TLR4 in dendritic cells-implications for diet-induced insulin resistance. Mol Nutr Food Res 2012, 56:1212-1222.

52. Myles IA, Fontecilla NM, Janelsins BM, Vithayathil PJ, Segre JA, Datta SK Parental dietary fat intake alters offspring microbiome and immunity. $\mathrm{J}$ Immunol 2013, 191:3200-3209.

53. Galli C, Calder PC: Effects of fat and fatty acid intake on inflammatory and immune responses: a critical review. Ann Nutr Metab 2009, 55:123-139.

54. Deopurkar R, Ghanim H, Friedman J, Abuaysheh S, Sia CL, Mohanty P, Viswanathan P, Chaudhuri A, Dandona P: Differential effects of cream, glucose, and orange juice on inflammation, endotoxin, and the expression of Toll-like receptor-4 and suppressor of cytokine signaling-3. Diabetes Care 2010, 33:991-997.

55. Gabele E, Dostert K, Hofmann C, Wiest R, Scholmerich J, Hellerbrand C, Obermeier F: DSS induced colitis increases portal LPS levels and enhances hepatic inflammation and fibrogenesis in experimental NASH. $J$ Hepatol 2011, 55:1391-1399.

56. Ghanim H, Abuaysheh S, Sia CL, Korzeniewski K, Chaudhuri A, Fernandez-Real JM, Dandona P: Increase in plasma endotoxin concentrations and the expression of Toll-like receptors and suppressor of cytokine signaling-3 in mononuclear cells after a high-fat, high-carbohydrate meal: implications for insulin resistance. Diabetes Care 2009, 32:2281-2287.

57. Cuda C, Badawi A, Karmali M, El-Sohemy A: Polymorphisms in Toll-like receptor 4 are associated with factors of the metabolic syndrome and modify the association between dietary saturated fat and fasting high-density lipoprotein cholesterol. Metabolism 2011, 60:1131-1135.

58. Kiechl S, Lorenz E, Reindl M, Wiedermann CJ, Oberhollenzer F, Bonora E, Willeit J, Schwartz DA: Toll-like receptor 4 polymorphisms and atherogenesis. N Engl J Med 2002, 347:185-192.

59. Chait A, Kim F: Saturated fatty acids and inflammation: Who pays the Toll?. J of the American Heart Association 2010, 30:692-693.

60. Laugerette F, Furet JP, Debard C, Daira P, Loizon E, Geloen A, Soulage CO, Simonet C, Lefils-Lacourtablaise J, Bernoud-Hubac N, Bodennec J, Peretti N Vidal H, Michalski MC: Oil composition of high-fat diet affects metabolic inflammation differently in connection with endotoxin receptors in mice. Am J Physiol Endocrinol Metab 2012, 302:E374-E386.

61. Liu J, Hu S, Cui Y, Sun MK, Xie F, Zhang Q, Jin J: Saturated fatty acids up-regulate COX-2 expression in prostate epithelial cells via toll-like receptor 4/NF-kappaB signaling. Inflammation 2013, 37(2):467-477.

62. Frommer KW, Schaffler A, Rehart S, Lehr A, Muller-Ladner U, Neumann E: Free fatty acids: potential proinflammatory mediators in rheumatic diseases. Ann Rheum Dis 2013, 0:1-8.
63. Calder PC: Fatty acids and immune function: relevance to inflammatory bowel diseases. Int Rev Immunol 2009, 28:506-534.

64. Innis SM: Dietary lipids in early development: relevance to obesity, immune and inflammatory disorders. Curr Opin Endocrinol Diabetes Obes 2007, 14:359-364

65. Kuhnt K, Wagner A, Kraft J, Basu S, Jahreis G: Dietary supplementation with 11trans- and 12trans-18:1 and oxidative stress in humans. Am J Clin Nutr 2006, 84:981-988.

66. Ghosh S, Kewalramani G, Yuen G, Pulinilkunnil T, An D, Innis SM, Allard MF, Wambolt RB, Qi D, Abrahani A, Rodrigues B: Induction of mitochondrial nitrative damage and cardiac dysfunction by chronic provision of dietary omega- 6 polyunsaturated fatty acids. Free Radic Biol Med 2006, 41:1413-1424.

67. Viswanathan S, Hammock BD, Newman JW, Meerarani P, Toborek M, Hennig $B$ : Involvement of CYP 2C9 in mediating the proinflammatory effects of linoleic acid in vascular endothelial cells. J Am Coll Nutr 2003, 22:502-510.

68. Johnson $\mathrm{GH}$, Fritsche $\mathrm{K}$ : Effect of dietary linoleic acid on markers of inflammation in healthy persons: a systematic review of randomized controlled trials. J Acad Nutr Diet 2012, 112:1029-1041. 1041 e1021-1015.

69. Fantuzzi G: Adipose tissue, adipokines, and inflammation. J Allergy Clin Immunol 2005, 115:911-919. quiz 920.

70. Colombel JF, Solem CA, Sandborn WJ, Booya F, Loftus EV Jr, Harmsen WS, Zinsmeister AR, Bodily KD, Fletcher JG: Quantitative measurement and visual assessment of ileal Crohn's disease activity by computed tomography enterography: correlation with endoscopic severity and C reactive protein. Gut 2006, 55:1561-1567.

71. Mozaffarian D, Pischon T, Hankinson SE, Rifai N, Joshipura K, Willett WC, Rimm EB: Dietary intake of trans fatty acids and systemic inflammation in women. Am J Clin Nutr 2004, 79:606-612.

72. Weylandt KH, Chiu C-Y, Gomolka B, Waechter SF, Wiedenmann B: Omega-3 fatty acids and their lipid mediators: towards an understanding of resolvin and protectin formation. Prostaglandins Other Lipid Mediat 2012, 97:73-82.

73. Calder PC: Omega-3 fatty acids and inflammatory processes. Nutrients 2010, 2:355-374.

74. Fredman G, Oh SF, Ayilavarapu S, Hasturk H, Serhan CN, Van Dyke TE: Impaired phagocytosis in localized aggressive periodontitis: rescue by Resolvin E1. PLoS One 2011, 6:e24422.

75. Shek LP, Chong MF-F, Lim JY, Soh S-E, Chong Y-S: Role of dietary longchain polyunsaturated fatty acids in infant allergies and respiratory diseases. Clin Dev Immun 2012, 2012:1-8.

76. Kremmyda LS, Vlachava M, Noakes PS, Diaper ND, Miles EA, Calder PC: Atopy risk in infants and children in relation to early exposure to fish, oily fish, or long-chain omega-3 fatty acids: a systematic review. Clin Rev Allergy Immunol 2011, 41:36-66.

77. Nwaru Bl, Erkkola M, Lumia M, Kronberg-Kippila C, Ahonen S, Kaila M, Ilonen J, Simell O, Knip M, Veijola R, Virtanen SM: Maternal intake of fatty acids during pregnancy and allergies in the offspring. Br J Nutr 2012, 108:720-732.

78. Levy BD: Resolvins and protectins: Natural pharmacophores for resolution biology. Prostaglandins Leukot Essent Fatty Acids 2010, 82:327-332

79. Ariel A, Serhan CN: Resolvins and protectins in the termination program of acute inflammation. Trends Immunol 2007, 28:176-183.

80. Merched AJ, Ko K, Gotlinger KH, Serhan CN, Chan L: Atherosclerosis: evidence for impairment of resolution of vascular inflammation governed by specific lipid mediators. FASEB J 2008, 22:3595-3606.

81. Lee JY, Plakidas A, Lee WH, Heikkinen A, Chanmugam P, Bray G, Hwang DH: Differential modulation of Toll-like receptors by fatty acids: preferential inhibition by n-3 polyunsaturated fatty acids. J Lipid Res 2003, 44:479-486.

82. Lee $J Y$, Zhao L, Hwang DH: Modulation of pattern recognition receptormediated inflammation and risk of chronic diseases by dietary fatty acids. Nutr Rev 2010, 68:38-61.

83. Junker Y, Zeissig S, Kim SJ, Barisani D, Wieser H, Leffler DA, Zevallos V, Libermann TA, Dillon S, Freitag TL, Kelly CP, Schuppan D: Wheat amylase trypsin inhibitors drive intestinal inflammation via activation of toll-like receptor 4. J Exp Med 2012, 209:2395-2408.

84. Vader LW, de Ru A, van der Wal Y, Kooy YM, Benckhuijsen W, Mearin ML, Drijfhout JW, van Veelen P, Koning F: Specificity of tissue transglutaminase explains cereal toxicity in celiac disease. J Exp Med 2002, 195:643-649. 
85. Lundin KE, Sollid LM, Qvigstad E, Markussen G, Gjertsen HA, Ek J, Thorsby E T lymphocyte recognition of a celiac disease-associated cis- or trans-encoded HLA-DQ alpha/beta-heterodimer. J Immunol 1990, 145:136-139.

86. Lundin KE, Scott H, Fausa O, Thorsby E, Sollid LM: T cells from the small intestinal mucosa of a DR4, DQ7/DR4, DQ8 celiac disease patient preferentially recognize gliadin when presented by DQ8. Hum Immunol 1994, 41:285-291.

87. Johansen BH, Jensen T, Thorpe CJ, Vartdal F, Thorsby E, Sollid LM: Both alpha and beta chain polymorphisms determine the specificity of the disease-associated HLA-DQ2 molecules, with beta chain residues being most influential. Immunogenetics 1996, 45:142-150.

88. Kagnoff MF: Celiac disease: pathogenesis of a model immunogenetic disease. J Clin Invest 2007, 117:41-49.

89. Johnson MW, Ellis HJ, Asante MA, Ciclitira PJ: Celiac disease in the elderly. Nat Clin Pract Gastroenterol Hepatol 2008, 5:697-706.

90. Chen TS, Chen PS: Intestinal autointoxication: a medical leitmotif. J Clin Gastroenterol 1989, 11:434-441.

91. Stecher B, Hardt WD: Mechanisms controlling pathogen colonization of the gut. Curr Opin Microbiol 2011, 14:82-91.

92. Brown K, DeCoffe D, Molcan E, Gibson DL: Diet-induced dysbiosis of the intestinal microbiota and the effects on immunity and disease. Nutrients 2012, 4:1095-1119.

93. Ghosh S, DeCoffe D, Brown K, Rajendiran E, Estaki M, Dai C, Yip A, Gibson DL: Fish oil attenuates omega- 6 polyunsaturated fatty acid-induced dysbiosis and infectious colitis but impairs LPS dephosphorylation activity causing sepsis. PLoS One 2013, 8:e55468.

94. Spreadbury I: Comparison with ancestral diets suggests dense acellular carbohydrates promote an inflammatory microbiota, and may be the primary dietary cause of leptin resistance and obesity. Diabetes Metab Syndr Obes 2012, 5:175-189.

95. Berg AM, Kelly CP, Farraye FA: Clostridium difficile infection in the inflammatory bowel disease patient. Inflamm Bowel Dis 2013, 19:194-204.

96. Begley M, Hill C, Gahan CG: Bile salt hydrolase activity in probiotics. Appl Environ Microbiol 2006, 72:1729-1738.

97. Belenguer A, Duncan SH, Calder AG, Holtrop G, Louis P, Lobley GE, Flint HJ: Two routes of metabolic cross-feeding between Bifidobacterium adolescentis and butyrate-producing anaerobes from the human gut. Appl Environ Microbiol 2006, 72:3593-3599.

98. De Vuyst L, Leroy F: Cross-feeding between bifidobacteria and butyrate-producing colon bacteria explains bifdobacterial competitiveness, butyrate production, and gas production. Int J Food Microbio/ 2011, 149:73-80.

99. Koropatkin NM, Cameron EA, Martens EC: How glycan metabolism shapes the human gut microbiota. Nat Rev Microbiol 2012, 10:323-335.

100. Duncan SH, Belenguer A, Holtrop G, Johnstone AM, Flint HJ, Lobley GE: Reduced dietary intake of carbohydrates by obese subjects results in decreased concentrations of butyrate and butyrate-producing bacteria in feces. Appl Environ Microbiol 2007, 73:1073-1078.

101. Abell GC, Cooke CM, Bennett CN, Conlon MA, McOrist AL: Phylotypes related to Ruminococcus bromii are abundant in the large bowel of humans and increase in response to a diet high in resistant starch. FEMS Microbiol Ecol 2008, 66:505-515.

102. De Filippo C, Cavalieri D, Di Paola M, Ramazzotti M, Poullet JB, Massart S, Collini S, Pieraccini G, Lionetti P: Impact of diet in shaping gut microbiota revealed by a comparative study in children from Europe and rural Africa. Proc Natl Acad Sci U S A 2010, 107:14691-14696.

103. Chassard C, Lacroix C: Carbohydrates and the human gut microbiota. Curr Opin Clin Nutr Metab Care 2013, 16:453-460.

104. Payne AN, Chassard C, Lacroix C: Gut microbial adaptation to dietary consumption of fructose, artificial sweeteners and sugar alcohols: implications for host-microbe interactions contributing to obesity. Obes Rev 2012, 13:799-809.

105. Geuns JM: Stevioside. Phytochemistry 2003, 64:913-921.

106. Normen L, Laerke HN, Jensen BB, Langkilde AM, Andersson H: Smallbowel absorption of $\mathrm{D}$-tagatose and related effects on carbohydrate digestibility: an ileostomy study. Am J Clin Nutr 2001, 73:105-110.

107. Maslowski KM, Vieira AT, Ng A, Kranich J, Sierro F, Schilter HC, Rolph MS, Mackay F, Artis D, Xavier RJ, Teixeira MM, Mackay CR: Regulation of inflammatory responses by gut microbiota and chemoattractant receptor GPR43. Nature 2009, 461:1282-1286.
108. Beauchamp GK, Mennella JA: Flavor perception in human infants: development and functional significance. Digestion 2011, 83(Suppl 1):1-6.

109. Funkhouser LJ, Bordenstein SR: Mom knows best: the universality of maternal microbial transmission. PLOS Biol 2013, 11:e1001631.

110. Jimenez E, Marin ML, Martin R, Odriozola JM, Olivares M, Xaus J, Fernandez $L$, Rodriguez JM: Is meconium from healthy newborns actually sterile? Res Microbiol 2008, 159:187-193.

111. Du Y, Yang M, Lee $S$, Behrendt $C L$, Hooper LV, Saghatelian A, Wan Y: Maternal western diet causes inflammatory milk and TLR2/4-dependent neonatal toxicity. Genes Dev 2012, 26:1306-1311.

112. Jablonka E: Epigenetic variations in heredity and evolution. Clin Pharmacol Ther 2012, 92:683-688.

113. Tennis MA, Vanscoyk MM, Wilson LA, Kelley N, Winn RA: Methylation of Wnt7a is modulated by DNMT1 and cigarette smoke condensate in non-small cell lung cancer. PLoS One 2012, 7:e32921.

114. Winn RA, Marek L, Han SY, Rodriguez K, Rodriguez N, Hammond M, Van Scoyk M, Acosta H, Mirus J, Barry N, Bren-Mattison Y, Van Raay TJ, Nemenoff RA, Heasley LE: Restoration of Wnt-7a expression reverses non-small cell lung cancer cellular transformation through frizzled-9-mediated growth inhibition and promotion of cell differentiation. J Biol Chem 2005, 280:19625-19634.

115. Karmaus W, Ziyab AH, Everson T, Holloway JW: Epigenetic mechanisms and models in the origins of asthma. Curr Opin Allergy Clin Immunol 2013 13:63-69.

116. Vanderhoof JA, Mitmesser SH: Probiotics in the management of children with allergy and other disorders of intestinal inflammation. Benef Microbes 2010, 1:351-356.

117. Peterson RA: Regulatory T-cells: diverse phenotypes integral to immune homeostasis and suppression. Toxicol Pathol 2012, 40:186-204.

118. Geuking MB, Cahenzli J, Lawson MA, Ng DC, Slack E, Hapfelmeier S, McCoy KD, Macpherson AJ: Intestinal bacterial colonization induces mutualistic regulatory T cell responses. Immunity 2011, 34:794-806.

119. Lathrop SK, Bloom SM, Rao SM, Nutsch K, Lio CW, Santacruz N, Peterson DA Stappenbeck TS, Hsieh CS: Peripheral education of the immune system by colonic commensal microbiota. Nature 2011, 478:250-254

120. Nagano $Y$, Itoh K, Honda K: The induction of Treg cells by gut-indigenous Clostridium. Curr Opin Immunol 2012, 24:392-397.

121. Atarashi K, Tanoue T, Oshima K, Suda W, Nagano Y, Nishikawa H, Fukuda S, Saito T, Narushima S, Hase K, Kim S, Fritz JV, Wilmes P, Ueha S, Matsushima K, Ohno H, Olie B, Sakaguchi S, Taniguchi T, Morita H, Hattori M, Honda K: Treg induction by a rationally selected mixture of Clostridia strains from the human microbiota. Nature 2013, 500:232-236.

122. lemoli E, Trabattoni D, Parisotto S, Borgonovo L, Toscano M, Rizzardini G, Clerici M, Ricci E, Fusi A, De Vecchi E, Piconi S, Drago L: Probiotics reduce gut microbial translocation and improve adult atopic dermatitis. J Clin Gastroenterol 2012, 46(Suppl):S33-S40.

123. Halabi-Tawil M, Ruemmele FM, Fraitag S, Rieux-Laucat F, Neven B, Brousse $N$, De Prost $Y$, Fischer A, Goulet $O$, Bodemer $C$ : Cutaneous manifestations of immune dysregulation, polyendocrinopathy, enteropathy, X-linked (IPEX) syndrome. Br J Dermatol 2009, 160:645-651.

124. Wright GP, Ehrenstein MR, Stauss HJ: Regulatory T-cell adoptive immunotherapy: potential for treatment of autoimmunity. Expert Rev Clin Immunol 2011, 7:213-225

125. Buc M: Role of regulatory T cells in pathogenesis and biological therapy of multiple sclerosis. Mediators Inflamm 2013, 2013:963748.

126. Saurer $L$, Mueller $C:$ T cell-mediated immunoregulation in the gastrointestinal tract. Allergy 2009, 64:505-519.

127. Katoh $H$, Zheng P, Liu Y: FOXP3: genetic and epigenetic implications for autoimmunity. J Autoimmun 2013, 41:72-78.

128. He YQ, Bo Q, Yong W, Qiu ZX, Li YL, Li WM: FoxP3 genetic variants and risk of non-small cell lung cancer in the Chinese Han population. Gene 2013, 531:422-425.

129. Zhao L, Yang J, Wang HP, Liu RY: Imbalance in the Th17/Treg and cytokine environment in peripheral blood of patients with adenocarcinoma and squamous cell carcinoma. Med Oncol 2013, 30:461.

130. Noval Rivas M, Burton OT, Wise P, Zhang YQ, Hobson SA, Garcia Lloret M, Chehoud C, Kuczynski J, DeSantis T, Warrington J, Hyde ER, Petrosino JF, Gerber GK, Bry L, Oettgen HC, Mazmanian SK, Chatila TA: A microbiota signature associated with experimental food allergy promotes allergic sensitization and anaphylaxis. J Allergy Clin Immunol 2013, 131:201-212.

131. Ji GE: Probiotics in primary prevention of atopic dermatitis. Forum Nutr 2009, 61:117-128. 
132. Braat $H$, Rottiers $P$, Hommes DW, Huyghebaert N, Remaut E, Remon JP, van Deventer SJ, Neirynck S, Peppelenbosch MP, Steidler L: A phase I trial with transgenic bacteria expressing interleukin-10 in Crohn's disease. Clin Gastroenterol Hepatol 2006, 4:754-759.

133. Messaoudi M, Violle N, Bisson JF, Desor D, Javelot H, Rougeot C: Beneficial psychological effects of a probiotic formulation (Lactobacillus helveticus R0052 and Bifidobacterium longum R0175) in healthy human volunteers. Gut Microbes 2011, 2:256-261.

134. Foster JA, McVey Neufeld KA: Gut-brain axis: how the microbiome influences anxiety and depression. Trends Neurosci 2013, 36:305-312.

135. Gareau MG, Sherman PM, Walker WA: Probiotics and the gut microbiota in intestinal health and disease. Nat Rev Gastroenterol Hepatol 2010, 7:503-514.

136. Myles I, Pincus NB, Fontecilla NM, Datta SK: Effects of parental omega-3 fatty acid intake on offspring microbiome and immunity. PLoS One 2013 9(1):e87181

137. Murri M, Leiva I, Gomez-Zumaquero JM, Tinahones FJ, Cardona F Soriguer F, Queipo-Ortuno MI: Gut microbiota in children with type 1 diabetes differs from that in healthy children: a case-control study. BMC Med 2013, 11:46.

138. Chen W, Liu F, Ling Z, Tong $X$, Xiang C: Human intestinal lumen and mucosa-associated microbiota in patients with colorectal cancer. PLoS One 2012, 7:e39743.

139. Mabrok HB, Klopfleisch R, Ghanem KZ, Clavel T, Blaut M, Loh G: Lignan transformation by gut bacteria lowers tumor burden in a gnotobiotic rat model of breast cancer. Carcinogenesis 2012, 33:203-208.

140. Rajilic-Stojanovic M, Biagi E, Heilig HG, Kajander K, Kekkonen RA, Tims S, de Vos WM: Global and deep molecular analysis of microbiota signatures in fecal samples from patients with irritable bowel syndrome. Gastroenterology 2011, 141:1792-1801.

141. Mondot S, Kang S, Furet JP, Aguirre de Carcer D, McSweeney C, Morrison M, Marteau P, Dore J, Leclerc M: Highlighting new phylogenetic specificities of Crohn's disease microbiota. Inflamm Bowel Dis 2011, 17:185-192.

142. Swidsinski A, Weber J, Loening-Baucke V, Hale LP, Lochs H: Spatial organization and composition of the mucosal flora in patients with inflammatory bowel disease. J Clin Microbiol 2005, 43:3380-3389.

143. van de Merwe JP, Mol GJ: A possible role of Eubacterium and Peptostreptococcus species in the aetiology of Crohn's disease. Antonie Van Leeuwenhoek 1980, 46:587-593.

144. Ridaura VK, Faith JJ, Rey FE, Cheng J, Duncan AE, Kau AL, Griffin NW Lombard V, Henrissat B, Bain JR, Meuhlbauer MJ, Ikayeva O, Semenkovich CF, Funai K, Hayashi DK, Lyle BJ, Martini MC, Ursell LK, Clemente JC, Van Treuren W, Walters WA, Knight R, Newgard CB, Heath AC, Gordon Jl: Gut microbiota from twins discordant for obesity modulate metabolism in mice. Science 2013, 341:1241214.

145. Koeth RA, Wang Z, Levison BS, Buffa JA, Org E, Sheehy BT, Britt EB, Fu X, Wu Y, Li L, Wu GD, Lewis JD, Warrier M, Brown JM, Krauss RM, Tang WH, Bushman FD, Lusis AJ, Hazen SL: Intestinal microbiota metabolism of L-carnitine, a nutrient in red meat, promotes atherosclerosis. Nat Med 2013, 19:576-585.

146. Ley SH, Sun Q, Willett WC, Eliassen AH, Wu K, Pan A, Grodstein F, Hu FB: Associations between red meat intake and biomarkers of inflammation and glucose metabolism in women. Am J Clin Nutr 2013, 99(2):352-360.

147. Micha R, Michas G, Mozaffarian D: Unprocessed red and processed meats and risk of coronary artery disease and type 2 diabetes-an updated review of the evidence. Curr Atheroscler Rep 2012, 14:515-524.

148. Bjelakovic G, Nikolova D, Gluud LL, Simonetti RG, Gluud C: Mortality in randomized trials of antioxidant supplements for primary and secondary prevention: systematic review and meta-analysis. JAMA 2007, 297:842-857.

149. Key TJ, Schatzkin A, Willett WC, Allen NE, Spencer EA, Travis RC: Diet, nutrition and the prevention of cancer. Public Health Nutr 2004, 7:187-200.

150. Milner JA: Nutrition and cancer: essential elements for a roadmap. Cancer Lett 2008, 269:189-198.

151. Milner JA: Preclinical perspectives on garlic and cancer. J Nutr 2006, 136:827S-831S.

152. Krishnan AV, Swami S, Moreno J, Bhattacharyya RB, Peehl DM, Feldman D: Potentiation of the growth-inhibitory effects of vitamin $D$ in prostate cancer by genistein. Nutr Rev 2007, 65:S121-S123.

153. Helicobacter, Cancer Collaborative G: Gastric cancer and Helicobacter pylori: a combined analysis of 12 case control studies nested within prospective cohorts. Gut 2001, 49:347-353.
154. Humans IWGotEoCRt: IARC monographs on the evaluation of carcinogenic risks to humans. Ingested nitrate and nitrite, and cyanobacterial peptide toxins. IARC Monogr Eval Carcinog Risks Hum 2010, 94:v-vii. 1-412.

155. Valdes-Ramos R, Benitez-Arciniega AD: Nutrition and immunity in cancer. Br J Nutr 2007, 98(Suppl 1):S127-S132

156. Sharp L, Chilvers CE, Cheng KK, McKinney PA, Logan RF, Cook-Mozaffari P, Ahmed A, Day NE: Risk factors for squamous cell carcinoma of the oesophagus in women: a case-control study. Br J Cancer 2001, 85:1667-1670.

157. Glade MJ: Food, nutrition, and the prevention of cancer: a global perspective. American Institute for Cancer Research/World Cancer Research Fund, American Institute for Cancer Research, 1997. Nutrition 1999, 15:523-526.

158. Norat T, Lukanova A, Ferrari P, Riboli E: Meat consumption and colorectal cancer risk: dose-response meta-analysis of epidemiological studies. Int J Cancer 2002, 98:241-256.

159. Howe GR, Aronson KJ, Benito E, Castelleto R, Cornee J, Duffy S, Gallagher RP, Iscovich JM, Deng-ao J, Kaaks R, Kune GA, Kune S, Lee HP, Lee M, Miller AB, Peters RK, Potter JD, Riboli E, Slattery ML, Trichopoulos D, Tuyns A, Tzonou A, Watson LF, Whittemore AS, Wu-Williams AH, Shu Z: The relationship between dietary fat intake and risk of colorectal cancer: evidence from the combined analysis of 13 case-control studies. Cancer Causes Control 1997, 8:215-228

160. Hamajima N, Hirose K, Tajima K, Rohan T, Calle EE, Heath CW Jr, Coates RJ, Liff JM, Talamini R, Chantarakul N, Koetswang S, Rachawat D, Morabia A, Schuman L, Stewart W, Szkio M, Bain C, Schofield F, Siskind V, Band P, Coldman AJ, Gallagher RP, Hislop TG, Yang P, Kolonel LM, Nomura AM, $\mathrm{Hu}$ J, Johnson KC, Mao Y, De Sanjose S, et al: Alcohol, tobacco and breast cancer-collaborative reanalysis of individual data from 53 epidemiological studies, including 58,515 women with breast cancer and 95,067 women without the disease. Br J Cancer 2002, 87:1234-1245.

161. Yao D, Shi W, Gou Y, Zhou X, Yee Aw T, Zhou Y, Liu Z: Fatty acid-mediated intracellular iron translocation: a synergistic mechanism of oxidative injury. Free Radic Biol Med 2005, 39:1385-1398.

162. Busch AK, Gurisik E, Cordery DV, Sudlow M, Denyer GS, Laybutt DR, Hughes WE, Biden TJ: Increased fatty acid desaturation and enhanced expression of stearoyl coenzyme A desaturase protects pancreatic beta-cells from lipoapoptosis. Diabetes 2005, 54:2917-2924.

163. Atshaves BP, Storey SM, Petrescu A, Greenberg CC, Lyuksyutova OI, Smith R 3rd, Schroeder F: Expression of fatty acid binding proteins inhibits lipid accumulation and alters toxicity in L cell fibroblasts. Am J Physio/ Cell Physiol 2002, 283:C688-C703.

164. Theodoratou E, McNeill G, Cetnarskyj R, Farrington SM, Tenesa A, Barnetson R, Porteous M, Dunlop M, Campbell H: Dietary fatty acids and colorectal cancer: a case-control study. Am J Epidemiol 2007, 166:181-195.

165. Liu H, Heaney AP: Refined fructose and cancer. Expert Opin Ther Targets 2011, 15:1049-1059.

166. Ruxton $\mathrm{CH}$, Gardner EJ, McNulty HM: Is sugar consumption detrimental to health? a review of the evidence 1995-2006. Crit Rev Food Sci Nutr 2010, 50:1-19.

167. White JS: Challenging the fructose hypothesis: new perspectives on fructose consumption and metabolism. Adv Nutr 2013, 4:246-256.

168. Aune D, Chan DS, Vieira AR, Navarro Rosenblatt DA, Vieira R, Greenwood DC, Cade JE, Burley VJ, Norat T: Dietary fructose, carbohydrates, glycemic indices and pancreatic cancer risk: a systematic review and metaanalysis of cohort studies. Ann Oncol 2012, 23:2536-2546.

169. Wright ME, Chang SC, Schatzkin A, Albanes D, Kipnis V, Mouw T, Hurwitz P, Hollenbeck A, Leitzmann MF: Prospective study of adiposity and weight change in relation to prostate cancer incidence and mortality. Cancer 2007, 109:675-684

170. Linos E, Holmes MD, Willett WC: Diet and breast cancer. Curr Oncol Rep 2007, 9:31-41

171. Carmichael AR: Obesity and prognosis of breast cancer. Obes Rev 2006, 7:333-340

172. Foksinski M, Gackowski D, Rozalski R, Siomek A, Guz J, Szpila A, Dziaman T, Olinski R: Effects of basal level of antioxidants on oxidative DNA damage in humans. Eur J Nutr 2007, 46:174-180.

173. Greenwald P: A favorable view: progress in cancer prevention and screening. Recent Results Cancer Res 2007, 174:3-17.

174. Weinstein SJ, Wright ME, Lawson KA, Snyder K, Mannisto S, Taylor PR, Virtamo J, Albanes D: Serum and dietary vitamin E in relation to prostate cancer risk. Cancer Epidemiol Biomarkers Prev 2007, 16:1253-1259. 
175. Wright ME, Weinstein SJ, Lawson KA, Albanes D, Subar AF, Dixon LB, Mouw T, Schatzkin A, Leitzmann MF: Supplemental and dietary vitamin E intakes and risk of prostate cancer in a large prospective study. Cancer Epidemiol Biomarkers Prev 2007, 16:1128-1135.

176. Mullin GE, Dobs A: Vitamin d and its role in cancer and immunity: a prescription for sunlight. Nutr Clin Pract 2007, 22:305-322.

177. Cui Y, Vogt S, Olson N, Glass AG, Rohan TE: Levels of zinc, selenium, calcium, and iron in benign breast tissue and risk of subsequent breast cancer. Cancer Epidemiol Biomarkers Prev 2007, 16:1682-1685.

178. Davis CD, Milner JA: Nutrigenomics, vitamin D and cancer prevention. J Nutrigenet Nutrigenomics 2011, 4:1-11.

179. Romagnolo DF, Davis CD, Milner JA: Phytoalexins in cancer prevention. Front Biosci 2012, 17:2035-2058

180. Sax HC: Immunonutrition and upper gastrointestinal surgery: what really matters. Nutr Clin Pract 2005, 20:540-543.

181. Sodergren MH, Jethwa $P$, Kumar S, Duncan HD, Johns T, Pearce CB: Immunonutrition in patients undergoing major upper gastrointestinal surgery: a prospective double-blind randomised controlled study. Scand J Surg 2010, 99:153-161.

182. Hennekens CH, Buring JE, Manson JE, Stampfer M, Rosner B, Cook NR, Belanger C, LaMotte F, Gaziano JM, Ridker PM, Willett W, Peto R: Lack of effect of long-term supplementation with beta carotene on the incidence of malignant neoplasms and cardiovascular disease. N Engl J Med 1996 334:1145-1149.

183. Omenn GS, Goodman GE, Thornquist MD, Balmes J, Cullen MR, Glass A, Keogh JP, Meyskens FL, Valanis B, Williams JH, Barnhart S, Hammar S: Effects of a combination of beta carotene and vitamin $A$ on lung cancer and cardiovascular disease. N Engl J Med 1996, 334:1150-1155.

184. Fortmann SP, Burda BU, Senger CA, Lin JS, Whitlock EP: Vitamin and mineral supplements in the primary prevention of cardiovascular disease and cancer: an updated systematic evidence review for the U.S. preventive services task force. Ann Intern Med 2013, 159(12):824-834.

185. Cortes-Jofre M, Rueda JR, Corsini-Munoz G, Fonseca-Cortes C, Caraballoso M, Bonfill Cosp X: Drugs for preventing lung cancer in healthy people. Cochrane Database Syst Rev 2012, 10:CD002141.

186. Bertuccio P, Rosato V, Andreano A, Ferraroni M, Decarli A, Edefonti V, La Vecchia C: Dietary patterns and gastric cancer risk: a systematic review and meta-analysis. Ann Oncol 2013, 24:1450-1458.

187. Liu RH: Health-promoting components of fruits and vegetables in the diet. Adv Nutr 2013, 4:384S-392S

188. Mosby T, Cosgrove M, Sarkardei S, Platt KL, Kaina B: Nutrition in adult and childhood cancer: role of carcinogens and anti-carcinogens. Anticancer Res 2012, 32:4171-4192.

189. Thomson CA: Diet and breast cancer: understanding risks and benefits. Nutr Clin Pract 2012, 27:636-650.

190. Flora SJ: Role of free radicals and antioxidants in health and disease. Cell Mol Biol (Noisy-le-Grand) 2007, 53:1-2.

191. Vainio H, Weiderpass E: Fruit and vegetables in cancer prevention Nutr Cancer 2006, 54:111-142.

192. Nishino H, Murakoshi M, Mou XY, Wada S, Masuda M, Ohsaka Y, Satomi Y, Jinno K: Cancer prevention by phytochemicals. Oncology 2005, 69(Suppl 1):38-40.

193. Ames BN: DNA damage from micronutrient deficiencies is likely to be a major cause of cancer. Mutat Res 2001, 475:7-20.

194. Gronbaek K, Hother C, Jones PA: Epigenetic changes in cancer. APMIS 2007, 115:1039-1059

195. Ross SA: Diet and DNA methylation interactions in cancer prevention. Ann N Y Acad Sci 2003, 983:197-207.

196. Bindels LB, Porporato P, Dewulf EM, Verrax J, Neyrinck AM, Martin JC, Scott KP, Buc Calderon P, Feron O, Muccioli GG, Sonveaux P, Cani PD, Delzenne NM: Gut microbiota-derived propionate reduces cancer cell proliferation in the liver. Br J Cancer 2012, 107:1337-1344.

197. Zhu Q, Gao R, Wu W, Qin H: The role of gut microbiota in the pathogenesis of colorectal cancer. Tumour Biol 2013, 34:1285-1300.

198. Cuevas-Ramos G, Petit CR, Marcq I, Boury M, Oswald E, Nougayrede JP: Escherichia coli induces DNA damage in vivo and triggers genomic instability in mammalian cells. Proc Natl Acad Sci U S A 2010, 107:11537-11542

199. Ellmerich S, Djouder N, Scholler M, Klein JP: Production of cytokines by monocytes, epithelial and endothelial cells activated by Streptococcus bovis. Cytokine 2000, 12:26-31.
200. Ross AC: Vitamin A and retinoic acid in T cell-related immunity. Am J Clin Nutr 2012, 96:1166S-1172S.

201. Hvistendahl M, Enserink M: GM research. Charges fly, confusion reigns over golden rice study in Chinese children. Science 2012, 337:1281.

202. Tang G, Hu Y, Yin SA, Wang Y, Dallal GE, Grusak MA, Russell RM: betaCarotene in Golden Rice is as good as beta-carotene in oil at providing vitamin A to children. Am J Clin Nutr 2012, 96:658-664.

203. Qaim M, Zilberman D: Yield effects of genetically modified crops in developing countries. Science 2003, 299:900-902.

204. Heinemann JA MM, Coray DS, Agapito-Tenfen SZ, Wen JD: Sustainability and innovation in staple crop production in the US Midwest. Int J Agri Sustain 2013, 12(1):1-18.

205. Stecker T: Drought-Tolerant Corn Efforts Show Positive Early Results. Sci Am 2012. Retrieved from http://www.scientificamerican.com/article/ drought-tolerant-corn-trials-show-positive-early-results/.

206. Gomez-Barbero M, Berbel J, Rodriguez-Cerezo E: Bt corn in Spain-the performance of the EU's first GM crop. Nat Biotechnol 2008, 26:384-386.

207. Nordlee JA, Taylor SL, Townsend JA, Thomas LA, Bush RK: Identification of a Brazil-nut allergen in transgenic soybeans. N Engl J Med 1996, 334:688-692.

208. Spok A, Gaugitsch H, Laffer S, Pauli G, Saito H, Sampson H, Sibanda E, Thomas W, van Hage M, Valenta R: Suggestions for the assessment of the allergenic potential of genetically modified organisms. Int Arch Allergy Immunol 2005, 137:167-180.

209. Martinez A, Reyes I, Reyes N: Cytotoxicity of the herbicide glyphosate in human peripheral blood mononuclear cells. Biomedica 2007, 27:594-604

210. Benachour N, Seralini GE: Glyphosate formulations induce apoptosis and necrosis in human umbilical, embryonic, and placental cells. Chem Res Toxicol 2009, 22:97-105.

211. Mesnage R, Clair E, Gress S, Then C, Szekacs A, Seralini GE: Cytotoxicity on human cells of Cry1 Ab and Cry1Ac Bt insecticidal toxins alone or with a glyphosate-based herbicide. J App/ Toxicol 2013, 33:695-699.

212. Carman JAVH, Ver Steeg LJ, Sneller VE, Robinson GW, Clinch-Jones CA, Haynes Jl, Edwards JW: A long-term toxicology study on pigs fed a combined genetically modified (GM) soy and GM maize diet. J Org Syst 2013, 8:38-54

213. Buzoianu SG, Walsh MC, Rea MC, O'Sullivan O, Crispie F, Cotter PD, Ross RP, Gardiner GE, Lawlor PG: The effect of feeding Bt MON810 maize to pigs for 110 days on intestinal microbiota. PLoS One 2012, 7:e33668.

214. Agency USEP: Bacillus thuringiensis Cry3Bb1 protein and the genetic material necessary for its production (Vector ZMIR13L) in event MON863 Corn (006484) fact sheet. 2005. Retrieved from http://www.epa.gov/ oppbppd1/biopesticides/ingredients_keep/factsheets/factsheet_006484.htm.

215. Schubbert RLC, Doerfler W: Ingested foreign (phage M13) DNA survives transiently in the gastrointestinal tract and enters the bloodstream of mice. Mol Gen Genet 1994, 242:495-504

216. Schubbert RRD, Schmitz B, Doerfler W: Foreign (M13) DNA ingested by mice reaches peripheral leukocytes, spleen, and liver via the intestinal wall mucosa and can be covalently linked to mouse DNA. Proc Natl Acad Sci 1997, 94:961-966.

217. Schubbert R, Hohlweg U, Renz D, Doerfler W: On the fate of orally ingested foreign DNA in mice: chromosomal association and placental transmission to the fetus. Mol Gen Genet 1998, 259:569-576.

218. Einspanier RKA, Kraft J, Aulrich K, Poser R, Schwagele F, Jahreis G, Flachowsky G: The fate of forage plant DNA in farm animals: a collaborative case-study investigating cattle and chicken fed recombinant plant material. Eur Food Res Technol 2001, 212:129-134.

219. Netherwood T, Martin-Orue SM, O'Donnell AG, Gockling S, Graham J, Math ers JC, Gilbert HJ: Assessing the survival of transgenic plant DNA in the human gastrointestinal tract. Nat Biotechnol 2004, 22:204-209.

220. Editorial Staff, DiChrinstina M: Scientific American perspectives. a seedy practice. Sci Am 2009, 301:28

221. Pace TW, Hu F, Miller AH: Cytokine-effects on glucocorticoid receptor function: relevance to glucocorticoid resistance and the pathophysiology and treatment of major depression. Brain Behav Immun 2007, 21:9-19.

222. Myles IA, Beakes D: An Allergy to Goldfish? Highlighting the Labeling Laws for Food Additives. World Allergy Organ J 2009, 2:314-316.

223. Koplin JJ, Allen KJ: Optimal timing for solids introduction - why are the guidelines always changing? Clin Exp Allergy 2013, 43:826-834.

224. Pansare M, Kamat D: Peanut allergy. Curr Opin Pediatr 2010, 22:642-646.

225. David TJ, Waddington E, Stanton RH: Nutritional hazards of elimination diets in children with atopic eczema. Arch Dis Child 1984, 59:323-325. 
226. Aldamiz-Echevarria L, Bilbao A, Andrade F, Elorz J, Prieto JA, Rodriguez-Soriano J: Fatty acid deficiency profile in children with food allergy managed with elimination diets. Acta Paediatr 2008, 97:1572-1576.

227. Drewnowski A, Darmon N: Food choices and diet costs: an economic analysis. J Nutr 2005, 135:900-904.

228. Wang MC, Kim S, Gonzalez AA, MacLeod KE, Winkleby MA: Socioeconomic and food-related physical characteristics of the neighbourhood environment are associated with body mass index. J Epidemiol Community Health 2007, 61:491-498.

229. Auerbach DI, Kellermann AL: A decade of health care cost growth has wiped out real income gains for an average US family. Health Aff (Millwood) 2011, 30:1630-1636.

230. Paez KA, Zhao L, Hwang W: Rising out-of-pocket spending for chronic conditions: a ten-year trend. Health Aff (Millwood) 2009, 28:15-25.

231. Cawley J, Meyerhoefer C: The medical care costs of obesity: an instrumental variables approach. J Health Econ 2012, 31:219-230.

232. Creel JS, Sharkey JR, Mclntosh A, Anding J, Huber JC Jr: Availability of healthier options in traditional and nontraditional rural fast-food outlets. BMC Public Health 2008, 8:395.

233. Brownell KD, Warner KE: The perils of ignoring history: Big Tobacco played dirty and millions died. How similar is Big Food? Milbank Q 2009, 87:259-294.

234. Romeo J, Warnberg J, Pozo T, Marcos A: Physical activity, immunity and infection. Proc Nutr Soc 2010, 69:390-399.

235. Packeu A, Chasseur C, Bladt S, Detandt M: The role of indoor pollution in the development and maintenance of chronic airway inflammation in children. B-ENT 2012, 8(Suppl 19):73-79.

236. Willett W, Manson J, Liu S: Glycemic index, glycemic load, and risk of type 2 diabetes. Am J Clin Nutr 2002, 76:274S-280S.

237. Banon S, Isenberg DA: Rheumatological manifestations occurring in patients with diabetes mellitus. Scand I Rheumatol 2013, 42:1-10.

238. Geerlings SE, Hoepelman Al: Immune dysfunction in patients with diabetes mellitus (DM). FEMS Immunol Med Microbiol 1999, 26:259-265.

239. Lamb MM, Myers MA, Barriga K, Zimmet PZ, Rewers M, Norris JM: Maternal diet during pregnancy and islet autoimmunity in offspring. Pediatr Diabetes 2008, 9:135-141.

240. de Koning L, Malik VS, Rimm EB, Willett WC, Hu FB: Sugar-sweetened and artificially sweetened beverage consumption and risk of type 2 diabetes in men. Am J Clin Nutr 2011, 93:1321-1327.

241. Kruijsen-Jaarsma M, Revesz D, Bierings MB, Buffart LM, Takken T: Effects of exercise on immune function in patients with cancer: a systematic review. Exerc Immunol Rev 2013, 19:120-143.

242. Walsh NP, Gleeson M, Shephard RJ, Gleeson M, Woods JA, Bishop NC, Fleshner M, Green C, Pedersen BK, Hoffman-Goetz L, Rogers CJ, Northoff H, Abbasi A, Simon P: Position statement. Part one: Immune function and exercise. Exerc Immunol Rev 2011, 17:6-63.

243. Andersen PH K, Gorbet DW, Brodbeck BV: Fatty Acid and Amino Acid Profiles of Selected Peanut Cultivars and Breeding Lines. J Food Composition Anal 1998, 11:100-111.

244. PJAJaK LS: US per capita food supply trends: more calories, refined carbohydrates, and fats. Food Rev 2002, 25:2-15.

245. Smith LC, AJ, Creveling RK, Hamblin CL: Lipid content and fatty acid profiles of various deep-fat fried foods. J Am Oil Chem Soc 1985, 62:996-999.

246. Boosalis M: Fatty acids. In Foods and their Health Implications. Edited by Chow C. Florida: CRC Press; 2008.

doi:10.1186/1475-2891-13-61

Cite this article as: Myles: Fast food fever: reviewing the impacts of the Western diet on immunity. Nutrition Journal 2014 13:61.

\section{Submit your next manuscript to BioMed Central and take full advantage of:}

- Convenient online submission

- Thorough peer review

- No space constraints or color figure charges

- Immediate publication on acceptance

- Inclusion in PubMed, CAS, Scopus and Google Scholar

- Research which is freely available for redistribution

Submit your manuscript at www.biomedcentral.com/submit
C Biomed Central 